\title{
Modernidade e minorias religiosas. Os arquivos da Igreja Lusitana (séculos XIX-XX) ${ }^{1}$
}

\author{
Modernity and religious minorities. \\ The archives of the Lusitanian Church (19th-20th centuries) \\ Modernidad y minorías religiosas. \\ Los archivos de la Iglesia Lusitana (siglos XIX-XX)
}

José António Afonso ${ }^{2}$; António Manuel S. P. Silva ${ }^{3}$

\section{Resumo}

A emergência em Portugal de correntes religiosas de matriz anglicana ao longo do século XIX corporizou-se, a partir de 1880, na Igreja Lusitana Católica Apostólica Evangélica, uma confissão religiosa formada do encontro de um conjunto de clérigos católicos insatisfeitos com o rumo doutrinal e a praxis litúrgica, pastoral e social da Igreja Católica Romana com movimentos protestantes e evangélicos que entretanto germinavam em vários pontos do País. Escorada nesta identidade de transição, a Igreja Lusitana pautou a sua atuação por forte investimento na educação popular e na criação de dispositivos promotores do ensino, do estímulo ao livre pensamento e da socialização assente nos princípios cristãos mas também de uma cidadania consciente e interventiva. Neste texto pretendemos, por um lado, apresentar, em termos genéricos, os fundos arquivísticos da Igreja Lusitana conservados, a par de uma importante hemeroteca e biblioteca históricas, e, por outro lado, apresentar o processo de criação do Arquivo Histórico desta igreja, evidenciando os constrangimentos e os resultados conseguidos até ao presente, salientando, deste modo, a sua crescente importância e valorização para o estudo e compreensão do papel das minorias religiosas na construção da modernidade.

Palavras-chave: Minorias religiosas; Igreja Lusitana; Anglicanismo; Arquivos institucionais

\footnotetext{
${ }^{1}$ Investigação inserida no Projeto: INOVAR - Roteiros da inovação pedagógica: Escolas e experiências de referência em Portugal no século XX, PTDC/MHC-CED/0893/2014, financiado através de fundos nacionais da FCT/MCTES-PT.

2 Doutor em Educação: História da Educação pela Universidade do Minho. Professor do Instituto de Educação e Investigador do Centro de Investigação em Educação da Universidade do Minho (Portugal). E-mail: jafonso@ie.uminho.pt

3 Mestre em Arqueologia (Univ. do Porto) e Doutorando em Estudos Culturais (Univ. Santiago de Compostela). Centro de Investigação Transdisciplinar Cultura, Espaço e Memória da Univ. do Porto. Diretor do Arquivo Histórico da Igreja Lusitana Católica Apostólica Evangélica. E-mail: arquivohistorico@igrejalusitana.org
} 


\begin{abstract}
The emergence in Portugal of Anglican shaped religious currents throughout the $19^{\text {th }}$ century culminated, in 1880, in the constitution of the Lusitanian Catholic Apostolic Evangelical Church. This religious body resulted from the intersection of several Catholic priests who are dissatisfied with the new doctrines and the liturgical, pastoral and social praxis of Roman Catholic Church with the protestant and evangelical movements that meanwhile had started its activity at various points of the Country. Based upon this melted ecclesiastical identity, the Lusitanian Church was guided in its actions by a strong investment in popular education and the creation of devices promoters of education, encouraging the free thought and socialization based on Christian principles but also of a conscious and interventive citizenship. In this text we aim to present, on the one hand, in general terms, Lusitanian Church's archivistic funds and its important historical library, and, on the other hand, present the process of creating the LC Historical Archive, highlighting the constraints and results achieved so far until now, stressing its growing importance and value to the study and understanding of the role of religious minorities in the construction of modernity.
\end{abstract}

Key-words: Religious minorities; Lusitanian Church; Anglicanism; Institutional archives

\title{
Resumen
}

La aparición en Portugal de las corrientes religiosas de matriz Anglicana a lo largo del siglo XIX se ha corporizado, a partir de 1880, en la Iglesia Lusitana Católica Apostólica Evangélica, una confesión religiosa formada del encuentro de un conjunto de clérigos católicos insatisfechos con el curso doctrinal y la praxis litúrgica, pastoral y social de la Iglesia Católica Romana con movimientos protestantes y evangélicos que germinaban en varios puntos del País. Sostenida en esta identidad de transición, la Iglesia Lusitana ha pautado su actuación por fuerte inversión en la educación popular y en la creación de dispositivos promotores de la enseñanza, del estímulo al libre pensamiento y de la socialización basada en los principios cristianos como también de una ciudadanía consciente e intervencionista. En este texto pretendemos, por un lado, presentar, en términos genéricos, los fondos archivísticos de la Iglesia Lusitana conservados, junto a una importante hemeroteca y biblioteca históricas, y, por otro lado, presentar el proceso de creación del Archivo Histórico de esta iglesia, evidenciando las limitaciones y los resultados obtenidos hasta el presente, subrayando de este modo su creciente importancia y valorización para el estudio y comprensión del papel de las minorías religiosas en la construcción de la modernidad.

Palabras clave: Minorías religiosas; Iglesia Lusitana; Anglicanismo; Archivos institucionales 


\section{Introdução}

Para se compreender, em toda a sua extensão, o papel desempenhado pelas instituições no processo de consolidação de sociedades plurais e democráticas, importará assinalar os contributos que as diferentes organizações foram produzindo ao longo do tempo. Contudo, muito desse património informacional, apenas sobrevive nos fragmentos que a historiografia vai reconstituindo, ou pela necessidade administrativa de preservar a documentação essencial para a salvaguarda das rotinas quotidianas dos atos institucionais.

O processo de construção da modernidade pressupões que historicamente se pensem as relações entre as religiões e o Estado, estabelecendo perspetivas conceptuais e metodológicas que rompam com as canónicas aproximações ao passado ancoradas numa projeção de um passado puro, sem qualquer tipo de conflitualidade e, inclusivamente, dinâmicas antinómicas.

A abordagem distinta aos problemas embebidos no tempo implica também que se ultrapassem as representações redutoras do passado - e a sua contemporânea utilização pública ou as meras políticas memorialísticas, arquivísticas e patrimoniais - pela galvanização de debates em que se dê nota dos progressos e resultados obtidos com as novas agendas historiográficas (ou diferentes formas de conhecimento do passado), assumindo a responsabilidade que os historiadores - o "dever de memória" reivindicado por Primo Levi têm neste processo.

As categorias fundamentais da compreensão histórica - tempo, memória, espaço e processo - acionam dinâmicas epistemológicas e metodológicas capazes de desconstruir a hegemonia da história historicizante a seu tempo denunciada por Lucien Febvre, questionando quer as formas de construção e de circulação dos discursos históricos, quer as dimensões teóricas, historiográficas e sociais que os suportam, reabilitando, por consequência, temporalidades, memórias, escalas e atores (ver, por exemplo, BOULAY, 2010; LEPETIT, 1995).

Ultrapassar a mera cronologia implica, assim, que nos adentremos em universos complexos, recuperando as lógicas de interação - na sua multidimensionalidade e na contextualização das sinergias das redes e do partenariado (materiais, simbólicas, humanas) como instituintes das identidades (organizacionais, económicas e culturais).

Esboçam-se, assim, as linhas essenciais para uma leitura da questão do nascimento dos movimentos religiosos acatólicos no Portugal oitocentista, matricida como uma trajetória de uma outra narrativa da modernidade, modalidade essa, no entanto, desconhecida ou esquecida por uma historiografia que opera o aggiornamento da génese de modelos e culturas cívicas empenhadas justamente no pluralismo religioso.

O confronto com periodizações singulares impõe que se indaguem as articulações, e relações, das instituições emergentes - centradas no presente texto na Igreja Lusitana (IL), enquanto uma das expressões da presença acatólica no espaço público - nomeadamente com o Estado, com os movimentos catalisadores da laicidade (ou secularização) da sociedade portuguesa e a dimensão politica ou cívica da Igreja Lusitana. Estes três vetores possibilitam equacionar o protestantismo como um projeto único que objetivamente erigiu os seus lugares de memória, em dilemáticas tensões com a sociedade - notem-se, a título de ilustração, dois momentos: durante a Monarquia Constitucional, o reconhecimento como minoria religiosa e na República, corolário da Lei da Separação das Igrejas do Estado, como religião minoritária -, que certamente provocaram reformulações no interior da instituição, sem originarem, contudo, abruptas ruturas nas relações já conservadas com o Estado, muito em particular no que concerne à legalização e inspeção das escolas protestantes, inferindo-se volens nolens que nos distintos regimes jurídicos, o protestantismo era uma realidade macrossociológica, social e cultural, que reenviava, sincronicamente, para práticas sociais e teológicas. 
Assinale-se também que as tensões, não só jurídicas, mas fundamentalmente de ordem simbólica - com reais expressões de violência -, persistem durante os períodos da Ditadura Militar e do Estado Novo, modificando-se com o restabelecimento da democracia, em 25 de abril de 1974, e a assunção plena da liberdade religiosa, mesmo num quadro Concordatário.

A institucionalização da Igreja Lusitana é objetivamente um processo histórico, perpassando diferentes regimes políticos, o que presume que a instituição se foi forjando em equivocas relações com o Estado, mas as missões da Igreja não se ancoraram na sua exclusividade salvífica: o percurso das comunidades (ou paróquias) atesta que a vertente cívica, declinada nas mais variegadas fórmulas - alfabetização, ensino, filantropia, sociabilidade - se materializou em associações infra institucionais, encastradas nas dinâmicas organizacionais participativas das comunidades, que alcandoraram uma dimensão social de inequívoca eficácia nas relações estabelecidas com o exterior (ou mundo social), inaugurando uma outra visão do mundo e da prática religiosa.

Nesta linha, pensar a criação de um Arquivo Histórico tem implícita a multidimensionalidade e complexidade organizacional, que também tem a sua trajetória socio histórica, o que requer estabelecer um mosaico de memórias que não se reduzem, portanto, ao documento escrito, ou fontes tradicionais, mas devem incluir fontes iconográficas, fontes orais e objetos de diferentes funcionalidades (paramentos, etc.), para além dos próprios espaços religiosos; fontes, em suma, imprescindíveis para se compreender a vida de uma instituição na sua territorialidade e na amplitude e perenidade, reintegrando ou integrando na sua história as ações e os atores, no sensível equilíbrio entre oralidade, memória e património (DESCAMPS, 2001).

\section{O protestantismo português e a Igreja Lusitana: conspecto histórico e fontes}

Até ao século XIX não houve praticamente qualquer expressão de protestantismo em Portugal. O estabelecimento da Inquisição (1536), provavelmente associada desde logo à censura preventiva e repressiva sobre todas as obras literárias, teológicas ou científicas que se publicassem ou circulassem no país (NEMÉSIO, 2011) impediu qualquer esboço de aproximação às correntes religiosas reformadas por parte de portugueses. Mesmo os intelectuais ou diplomatas que em resultado das suas viagens pela Europa contactaram com os ideários protestantes, chegando mesmo a privar ou a corresponder-se com humanistas ou reformistas, sentiram na pele (a maior parte das vezes com injustiça) as consequências dessas amizades «suspeitas», como ilustra o bem conhecido caso de Damião de Góis (1502-1574).

Os raros portugueses que publicamente aderiram ao protestantismo só o puderam fazer no estrangeiro, como João Ferreira de Almeida (1628-1691), o primeiro tradutor da Bíblia para português, ou o conhecido «Cavaleiro de Oliveira» (1702-1783). Até ao Liberalismo do século XIX apenas as comunidades estrangeiras podiam realizar cultos protestantes, na sua própria língua e ainda assim sob fortes restrições.

A revolução liberal de 1820, ditando o fim do Santo Ofício e da censura prévia, com a consequente liberdade de imprensa, a par de um diferente ambiente socio-político e cultural, além de outros fatores que aqui não cabe enunciar (RIBEIRO, 2001; SILVA, 2018a) permitiram por fim que, muito gradualmente e com grandes limitações, as crenças religiosas de além-Pirinéus chegassem a Portugal, primeiro entre os estrangeiros e pouco a pouco ganhando também adesões entre os nacionais.

Assim, já no segundo quartel do século XIX, os principais polos do protestantismo português situaram-se na Madeira e em Lisboa. Naquela ilha atlântica Robert Kalley, médico e pastor presbiteriano escocês, desenvolveu entre 1838 e 1846 um notável esforço assistencial, filantrópico e de evangelização, de que resultou um singular impacte social e uma 
perseguição religiosa sem precedentes em Portugal após a expulsão dos Judeus, levando à fuga de Kalley, sua esposa e milhares de madeirenses convertidos para as Américas (TESTA, 1963; GUICHARD, 1993a, 1993b, 1995a; ABREU, 2001; FERNANDES, 2004). Em Lisboa, Vicente Gómez y Tojar, um padre católico espanhol convertido ao anglicanismo, realizou trabalho de missionação de que resultou em 1839 a criação da «Capela da Propagação Evangélica do Filho de Deus», ativa até à década de 1870 e de cuja importância temos diversas notícias (MOREIRA, 1958; SILVA, 1995a).

Estas figuras contam-se certamente entre as primeiras entidades com produção documental e historiográfica sobre o protestantismo português. Da ação de Kalley e das suas comunidades na Madeira são certamente escassos os registos, considerando até as circunstâncias dramáticas que abruptamente liquidaram o movimento; mas o próprio Kalley editou em folheto (1875 [1843]) a memória desses tempos conturbados. Gómez y Tojar, personalidade que, à semelhança do escocês, suscitou grande prestígio social, não só registou alguma intervenção na imprensa periódica da época, como elaborou um livro de assentos paroquiais da sua comunidade, de que se conservam registos de diversos batismos e um matrimónio entre os anos de 1839 e 1870 (SILVA, 1995a).

Passando de lado outros focos e protagonistas, objeto de estudos recentes (AFONSO, 2009; LEITE, 2009; SILVA, 2011a, 2011b; 2016), situou-se no norte do país, em Vila Nova de Gaia e no Porto, desde os finais da década de 1860, um outro núcleo de grande relevância, quer no plano da história do protestantismo português, quer no que se refere à sua produção documental. Referimo-nos à ação de Diogo Cassels (1844-1923), fundador da Escola e Igreja do Torne, em Gaia (1868) e de um conjunto de pessoas com quem constituiu um polo de grande dinâmica, como o pastor metodista Robert Moreton, estabelecido no Porto desde 1871 e que em 1877 inaugurou a Igreja do Mirante (Porto) ou o ex-padre católico Guilherme Dias da Cunha, que nessa mesma década se lhes associou, entre outros (cfr. em especial ASPEY, 1971; SILVA, 1995a; PEIXOTO, 2001, 2005; AFONSO; SILVA, 2015; AFONSO; SILVA; LACERDA, 2016; SILVA, 2018b).

Desde então, passamos a contar com correspondências, relatórios, um ou outro registo fotográfico e sobretudo com publicações periódicas que davam conta dos esforços de alfabetização e instrução e dos «progressos do Evangelho em Portugal», como se dizia. $O$ Amigo da Infância (1876-1940) (AFONSO, 2014; AFONSO; SILVA, 2008) foi o primeiro jornal evangélico português dedicado ao público infantojuvenil, a que se seguiriam A Reforma (1877-c.1897), o primeiro jornal informativo e doutrinal protestante (SILVA, 2005), o Egreja Lusitana (1892-1923) (SILVA, 1995b) e outros no Norte do País. Diogo Cassels, por seu turno, foi o autor da primeira História da Reforma em Portugal, publicada n'O Evangelista (Lisboa) em 1897-1898 e revista e atualizada em livro mais tarde (CASSELS, 1908).

Em Lisboa, outros movimentos tinham lugar, destacando-se o que levou a que em meados da década de 1870 diversos padres católicos romanos se afastassem daquela confissão e, sob a influência do capelão anglicano em Lisboa, Thomas Pope, e de Herreros de Mora, expadre católico espanhol que estabelecera na capital uma igreja anglicana (AFONSO et alii, 2005), fundassem três congregações religiosas, agrupadas em 1878 em organização nacional de onde sairia em 1880 a Igreja Lusitana Católica Apostólica Evangélica (CASSELS, 1908; FIGUEIREDO, 1910; MOREIRA, 1949; SILVA, 1995a; MOREIRA, 1995; 2002; SANTOS, 1996-1997; AFONSO, 2013), data a partir da qual a produção documental da Igreja Lusitana (IL) é regular e sistemática. Desde esse ano de 1880, ano do seu sínodo constituinte, a Igreja Lusitana seguiu o seu caminho, contando entre os marcos fundamentais da sua existência os anos de 1958 - sagração do seu primeiro bispo - e 1980, ano em que foi integrada na Comunhão Anglicana, a comunhão mundial de Igrejas daquela tradição histórica e doutrinal. 


\section{A historiografia protestante no século $\mathrm{XX}$}

Para além de memórias e outras narrativas deixadas nas páginas da imprensa periódica, à historiografia protestante acrescentaram-se em 1901 o opúsculo de José Maria Barreto Introdução da Reforma em Portugal e o trabalho de Joaquim dos Santos Figueiredo História e Factos notáveis da História da Egreja Lusitana (edições em 1909 e 1910, a segunda revista e ampliada), devendo-se depois a Eduardo Moreira (1886-1980), o principal historiador do protestantismo português, as obras mais profundas e consistentes sobre estas dinâmicas religiosas (MOREIRA, 1913, 1949, 1957, 1958).

Omitindo contributos já citados ou mais pontuais, só a partir da década de 1980, surgiram trabalhos mais desenvolvidos sobre esta temática, merecendo destaque os estudos de Manuel Pedro Cardoso (1985, 1989, 1998), François Guichard (1990, 1993a, 1993b, 1995a, 1995b) e João Francisco Marques (1995, 1998), os dois últimos responsáveis pelo Seminário de Minorias Religiosas dos Mestrados em História Moderna e Contemporânea que tiveram lugar na Universidade do Porto ao longo da década de '90 (MARQUES; GUICHARD, 19961997). Desta iniciativa resultaram um conjunto de trabalhos (PEIXOTO, 1995a; MOREIRA, 1995; OLIVEIRA, 1996; COSTA, 1997; VIANA, 1999; LOPES, 2001) que marcaram uma época de fulgor no reavivamento dos estudos sobre o protestantismo em Portugal, entretanto acompanhados por diversas obras coletivas, como o volume Vila Nova de Gaia de há 100 anos. Colóquio comemorativo do centenário da igreja do Torne. (1995), os números temáticos da revista Lusotopie - Des protestantismes en "lusophonie catholique" (1998) e Dynamiques religieuses en lusophonie contemporaine (1999), o tomo da revista Lusitania Sacra "Protestantismo e Catolicismo nos séculos XIX e XX" (1999), o número monográfico "Minorías Religiosas en España y Portugal, ayer y hoy" dos Anales de Historia Contemporánea da Universidade de Murcia (2001) e ainda os dois dossiês temáticos da Revista Lusófona de Ciência das Religiões - "Nos 200 Anos da Sociedade Bíblica" (2005) e "O Protestantismo no espaço lusófono" (2006).

Nestas e noutras publicações vieram a lume trabalhos de enquadramento geral e revisão historiográfica (VAN DER GRIJP, 1999; SANTOS, 2001; 2002) ou votados a temas ou protagonistas particulares, de que podemos citar os de Vítor Neto (1998), Van der Grijp (1999), Luís Aguiar Santos (1996-1997, 2001, 2002, 2005), Fernando Peixoto (1995b, 1999, 2001, 2005) e, mais recentemente, Rita Mendonça Leite (2007-2008, 2009, 2012, 2016), para além dos nossos trabalhos elencados na bibliografia final.

\section{Os arquivos da Igreja Lusitana}

Os arquivos da Igreja Lusitana localizam-se a dois níveis de produção e custódia documental. No plano local, correspondente às comunidades ou paróquias ${ }^{4}$, a produção documental é muito diversificada, variando com a história de cada congregação, e apresenta distintos graus de preservação. As tipologias documentais incluem as séries de atas da junta paroquial $^{5}$, assentos de batismo, casamento ou funeral e outros registos associados ao culto e à vida das congregações, a que podem juntar-se, em muitas das congregações que tiveram escolas públicas, os registos próprios desta função. Esta documentação encontra-se normalmente nas paróquias, começando agora a ser reunida no Arquivo Histórico central.

\footnotetext{
${ }^{4}$ A Igreja Lusitana tem atualmente 13 comunidades ativas, localizadas essencialmente na franja litoral do país, desde o Porto ao Alentejo.

${ }^{5}$ Órgão de governo de cada paróquia, constituído pelo Pároco (tradicionalmente o presidente, que agora pode ser um leigo), outro clero da paróquia e por um número variável de membros eleitos pela comunidade.
} 
À escala nacional, a Igreja Lusitana constitui uma única diocese e é gerida por um sínodo $^{6}$ e pelo seu presidente ${ }^{7}$, funcionando entre as reuniões do sínodo uma comissão permanente. As principais séries documentais compreendem assim as atas deste orgão, a par de documentos de tesouraria, correspondências diversas, fundos relacionados com clérigos e outras personalidades e muita outra documentação bastante dispersa. Importa notar que tendo sido sempre uma igreja muito pequena e de parcos recursos, a Igreja Lusitana só na década de 1960 (e de forma permanente apenas desde 1981) pôde centralizar num espaço administrativo a documentação relacionada com a diocese e as funções do bispo e de outros órgãos nacionais.

\subsection{A organização do Arquivo Diocesano: dos primórdios ao AtoM}

Com exceção de alguns arquivos paroquiais, minimamente organizados pela ação voluntariosa, se bem que amadora, de alguns responsáveis locais, só a partir da década de 1980 foram feitas esforços consistentes de inventariação e organização do arquivo diocesano com metodologia moderna, inicialmente dirigidos ao arquivo administrativo corrente e depois alargados, de forma muito sumária, à documentação histórica.

Em finais da década de 1990, aproveitando financiamentos do governo português e de outras entidades públicas, foram realizados trabalhos de inventariação dos fundos documentais de uma das paróquias mais antigas (a igreja do Torne, em Vila Nova de Gaia, fundada em 1868), pouco depois alargados ao acervo fotográfico da mesma comunidade ${ }^{8}$. Já nos primeiros anos deste milénio, o trabalho foi alargado, numa base voluntária, aos fundos documentais e bibliográficos de outras comunidades lusitanas do norte do país, intervenção importante do ponto de vista de levantamento das existências e salvaguarda de algum material mais sensível. Todavia, por falta de condições físicas, infraestruturas e meios financeiros por parte da Igreja, estes registos foram feitos em fichas manuscritas que não chegaram a ser informatizadas ou em softwares entretanto descontinuados, o que limitou bastante a sua reutilização futura9 9 .

Em começos de 2015, fruto de uma nova visão no modo de encarar este património histórico da Igreja - traduzida nomeadamente pela contratação, em regime de meio-tempo, de uma técnica de arquivo - implementou-se um plano de médio-longo prazo visando o tratamento, organização e classificação sistemática da documentação do Arquivo Histórico da Igreja (diocese, paróquias, escolas e todas as entidades ligadas à Igreja); a divulgação desse acervo arquivístico, nomeadamente através da sua disponibilização através de uma plataforma web; o seu reacondicionamento físico em condições de conservação e acessibilidade adequadas e, ainda, a catalogação e reacondicionamento da Biblioteca Histórica da IL, com prioridade à disponibilização digital da hemeroteca.

O grau de desenvolvimento dos trabalhos para atingir estas metas é variável, mas alcançou já resultados significativos em vários domínios, do que aqui se pretende dar nota sumária.

\footnotetext{
${ }^{6}$ O Sínodo é o órgão máximo de governo da Igreja Lusitana, desde a sua fundação. É uma assembleia diocesana que reúne todo o clero da Igreja e um representante secular de todas as comunidades (modernamente, inclui também os leitores leigos e elementos de outras comissões e departamentos diocesanos).

${ }^{7}$ Que desde 1958, ano de sagração do seu primeiro bispo, coincide com o bispo diocesano.

${ }^{8}$ Tratou-se de um programa de inventariação do património cultural móvel, desenvolvido a nível nacional, sob a égide, no campo dos arquivos, do Instituto Português de Arquivos e que contou, no caso da Igreja Lusitana, com o apoio do Arquivo Distrital do Porto e do Instituto de Educação e Psicologia da Universidade do Minho.

${ }^{9}$ Primeiro no sistema de ARQBase, usado em Portugal na década de 1990, e depois no software Digitarq, desenvolvido pelo Arquivo Distrital do Porto sob a administração da Direção-Geral de Arquivos e com o apoio técnico da Universidade do Minho. A aplicação foi testada nos arquivos da Igreja Lusitana com vista à sua adoção por protocolo a celebrar com o Arquivo Distrital do Porto, uma vez que aquele software não era então disponibilizado em versão open-source, como viria a suceder desde 2009. Todavia, por falta de meios humanos da IL, esta intenção não viria a concretizar-se.
} 
Para além da colaboração regular (se bem que em regime laboral de meio-tempo) de uma especialista com formação técnica adequada, optou-se por utilizar como ferramenta informática uma aplicação de código aberto, o AtoM, um software de descrição e disponibilização de acervos arquivísticos muito maleável, baseado em normas de descrição arquivística do Conselho Internacional de Arquivos e especialmente desenhado para utilização em ambiente Web que tem vindo a assinalar crescente número de instituições utilizadoras, quer em Portugal, quer em muitos outros países ${ }^{10}$ (VIDAL, 2017).

Este software tem sido a principal ferramenta de descrição arquivística dos fundos documentais da Igreja Lusitana e da sua disponibilização pública, ações que muitas vezes coincidem no tempo, nomeadamente quando a documentação inventariada e descrita é assumida como de particular potencial informativo para a comunidade ${ }^{11}$. À data de redação deste texto encontram-se já descritos na plataforma www.http://arquivo.igreja-lusitana.org cerca de 2000 itens, (documentos avulsos, livros, processos, imagens, etc.), distribuídos por 35 fundos ou entidades produtoras, a que adiante faremos referência mais detalhada (Fig. 1).

Fig. 1 - Evolução do número de itens descritos na plataforma do Arquivo da Igreja Lusitana.

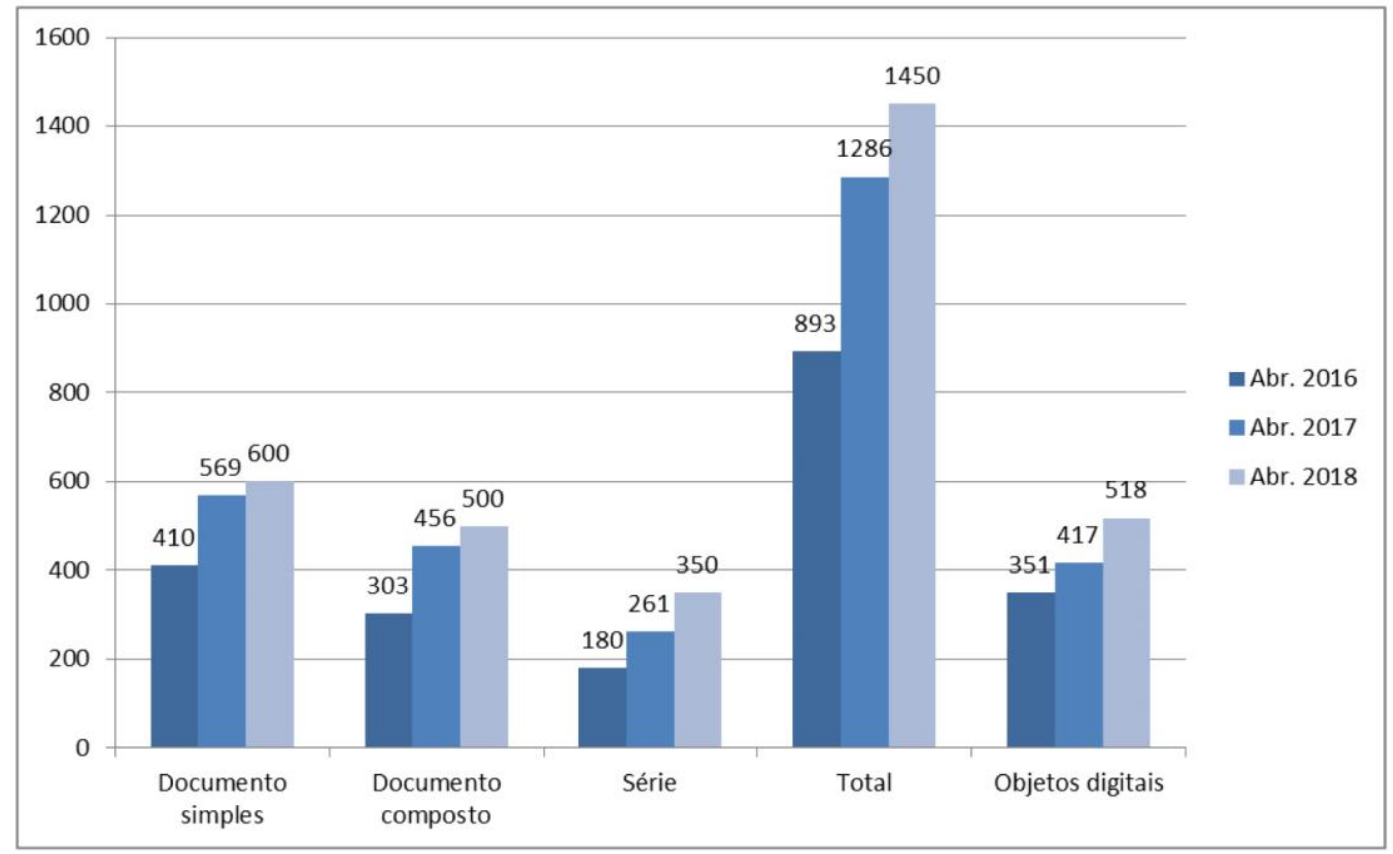

Fonte: Arq. Hist. Igreja Lusitana.

Outra área que tem evidenciado notáveis avanços é a da digitalização e disponibilização em linha da coleção de periódicos históricos da Igreja, cumprindo simultaneamente dois propósitos essenciais, o da sua preservação física, considerando o deficiente estado de conservação de muitos jornais antigos e a conveniência de evitar ao

10 O software ICA-AtoM (AtoM, Access to Memory) foi desenvolvido pela Artefactual Systems, sob patrocínio do Conselho Internacional de Arquivos e da UNESCO e teve a sua primeira versão, estável e aberta, em 2010, tendo sido apresentadas desde então várias versões. É um software livre, distribuído nos termos de uma licença GNU Affero General Public License (A-GPL 3.0) (Cf., CÊ; FLORES, 2016).

${ }^{11}$ Não é este o momento para uma avaliação técnica do uso do software AtoM para este arquivo, mas tratando-se de uma aplicação de código aberto em permanente melhoria e atualização, a sua utilização envolve um significativo investimento de know-how informático e de partilha de informação por uma já ampla comunidade de usuários do AtoM, tarefa de que se têm encarregado, com evidente sucesso, a arquivista Alexandra Silva Vidal e o eng ${ }^{\circ}$ Luís Massa, que constituem o núcleo técnico central do Arquivo. 
máximo o seu manuseamento; ao mesmo tempo que se possibilita a consulta em qualquer local de séries que, na generalidade dos casos, apenas se encontram completas na biblioteca da Igreja, estando mal representadas ou sendo mesmo inexistentes nas bibliotecas públicas portuguesas, incluindo a Biblioteca Nacional em Lisboa.

Considerando o interesse público da generalidade desses periódicos e a falta de meios técnicos e equipamentos no arquivo lusitano, foi celebrado em 2016 um protocolo de colaboração entre a Igreja e o Arquivo Municipal Sophia de Mello Breyner, do Município de Vila Nova de Gaia para a digitalização e disponibilização desses periódicos no portal desta instituição (CIRNE et. al. 2018). Desta forma, desde 2017 que no endereço https://arquivo.cm-gaia.pt/ podem encontrar-se, para leitura e descarga as séries integrais ou o mais completas conhecidas de jornais como o Capella do Torne/Egreja Lusitana (V. N. Gaia, 1892-1923), O Bom Pastor (V. N. Gaia, 1901-1922) e, mais recentemente, o mais antigo jornal protestante português - A Reforma (Porto, 1877-1889), a que se seguirão outros títulos ${ }^{12}$ (Fig. 2). Deve sublinhar-se, a propósito, que é a primeira vez em Portugal que séries completas de jornais históricos «protestantes» são disponibilizadas no portal eletrónico de um arquivo público. A par da disponibilização destes periódicos, tem sido reproduzida e colocada em acesso livre outra documentação considerada de interesse tanto para a Igreja como para o arquivo municipal, do que é exemplo a interessante série dos «Livros dos Benfeitores» das Escolas do Torne e do Prado, a que voltaremos a referir-nos.

Fig. 2 - Plataforma web do Arquivo Municipal Sophia de Mello Breyner (Vila Nova de Gaia), onde estão disponíveis vários jornais da Igreja Lusitana.

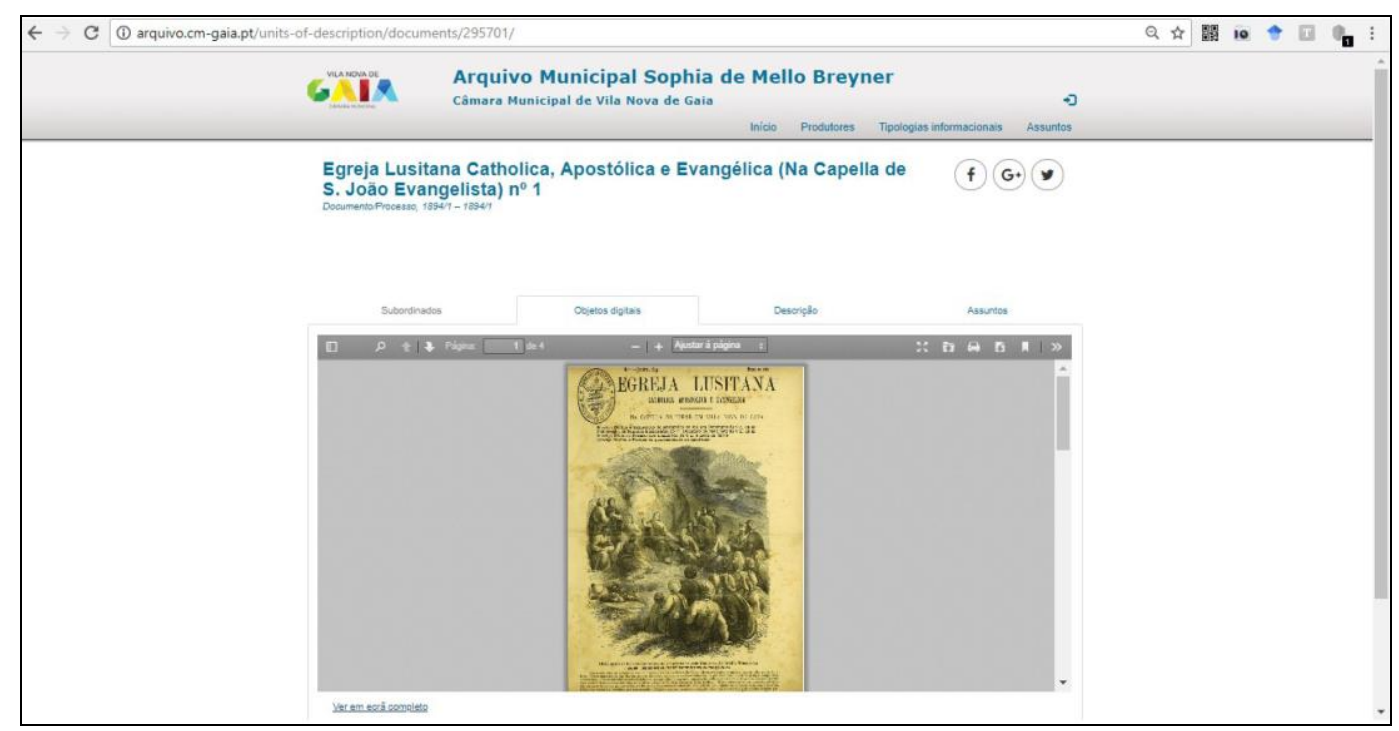

Fonte: www. https://arquivo.cm-gaia.pt/

Dos objetivos que mencionámos, o que se encontra ainda mais distante de concretização é o do reacondicionamento físico do Arquivo Histórico. Os espaços necessários e disponíveis para o efeito estão já identificados, mas a instalação definitiva do acervo tem vindo a registar algum atraso, por um lado pela falta de meios financeiros da Igreja Lusitana para um investimento que, envolvendo remodelações arquitetónicas e aquisição de equipamentos, é ainda significativo; por outro, pela natural ponderação que se exige em qualquer ação que implique a movimentação de importantes massas documentais.

12 Deve notar-se, a este propósito, a boa colaboração encetada com o arquivo e biblioteca da Igreja Evangélica Metodista Portuguesa, que facultou ao arquivo da Igreja Lusitana, para digitalização, alguns volumes dos jornais A Reforma e $O$ Bom Pastor em falta nas bibliotecas lusitanas. 


\subsection{Principais fundos, séries e tipologias documentais}

Numa panorâmica necessariamente breve, a documentação que integra o Arquivo Histórico da Igreja Lusitana distribui-se assim, no essencial, por cerca de três dezenas e meia de fundos, entendidos genericamente como entidades autónomas de produção documental.

O fundo diocesano é bastante irregular na sua composição, grau de preservação e organização, refletindo as dificuldades de administração centralizada da Igreja que referimos. A documentação mais antiga, ainda anterior à fundação da Igreja Lusitana (1880), é constituída pelos registos de batismo e casamento celebrados em Lisboa pelo Rev. Vicente Gómez y Tojar entre 1839 e 1870 (Fig. 3), a que se seguem, desde os finais da década de 1870, as séries de atas do sínodo e da comissão permanente, ininterruptas desde 1880. Algumas correspondências, registos biográficos de clérigos, fotografias e outros documentos constituem um núcleo bastante interessante mas pouco volumoso.

Fig. 3 - Página do livro de registos de batismo do presbítero episcopal Vicente Gómez y Tojar, 1839

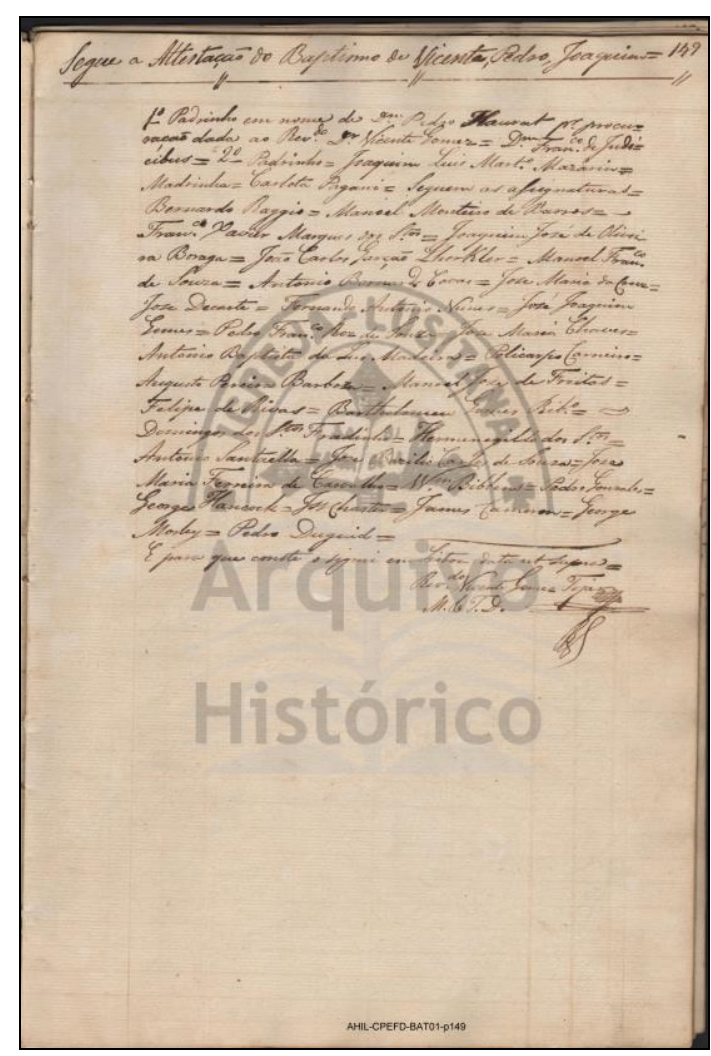

Fonte: Arq. Hist. Igreja Lusitana.

Com exceção das séries encadernadas, a documentação das primeiras décadas do século XX é bastante lacunar (ou achar-se-á talvez ainda por localizar), sendo principalmente a partir de meados do século XX que encontramos corpora documentais mais expressivos, principalmente associados aos primeiros bispos da Igreja, D. António Ferreira Fiandor (1958-1962) e D. Luís Pereira (1962-1980), incluindo correspondências, fotografias e muito material ainda por inventariar.

A partir de 1981 a documentação encontra-se de um modo geral bem preservada, se bem que a sua organização e acessibilidade seja muito variável, pela circunstância já observada da Igreja nunca ter podido dispor de técnicos de arquivo ou estruturas organizativas 
que permitissem um grande investimento nessas tarefas, naturalmente complexas pela natureza da instituição e das suas múltiplas relações com outras entidades do País e do estrangeiro. Nas últimas décadas, a generalização dos meios informáticos e a quase exclusividade da produção documental em suportes digitais geraram outro tipo de dificuldades e desafios que os profissionais das ciências da informação bem conhecem.

A inventariação e descrição dos arquivos paroquiais encontram-se em grau muito variável de execução, tanto mais que na sua maior parte se encontra ainda alojada nos imóveis das comunidades a que se refere. No Arciprestado do Norte (região do Porto e Vila Nova de Gaia), há um razoável conhecimento dos fundos de cada congregação, em resultado dos levantamentos feitos desde a década de 1990 e de estudos históricos monográficos entretanto realizados para algumas delas (SILVA, 2013, 2018b; SILVA; AFONSO, 2015; SILVA; AFONSO; VIDAL, 2016), a que deve acrescentar-se que o arquivo da igreja mais antiga, a de São João Evangelista (Torne), que data de 1868, foi o germe e o núcleo central da moderna dinamização do arquivo diocesano. Já no Arciprestado do Sul (região de Lisboa, Ribatejo, Setúbal e Alcácer do Sal), as incorporações paroquiais no arquivo diocesano são pontuais e o conhecimento dos acervos de cada comunidade é bem menor, sendo que parte delas são também de fundação mais recente (meados do século $\mathrm{XX}$ ) e registam por isso menor produção documental.

Entre os arquivos paroquiais variam quer as dimensões dos fundos, quer o seu grau de integridade, organização, acondicionamento e acessibilidade. De um modo geral a documentação encontra-se razoavelmente acondicionada, pelo menos no que se refere aos riscos mais imediatos. Todavia, como só pontualmente foi sujeita a ações de expurgo e desinfestação, acusa naturalmente a presença de insetos, fungos e outros elementos de deterioração. A sua organização e acessibilidade são também diversas: enquanto as séries de maior uso administrativo (atas, registos paroquiais, etc.) se encontram em livros encadernados e minimamente organizados, os maços e avulsos ocorrem ordinariamente dispersos, em dossiês, caixas ou gavetas e misturados com outros materiais. Em termos dimensionais, o arquivo paroquial mais extenso é o da paróquia de S. João Evangelista (Torne), estimado em cerca de quinze metros lineares, variando os das restantes comunidades entre um e seis metros cada.

A maior extensão deste arquivo é resultado, julgamos, quer do peso, personalidade e apetência pela memória histórica dos seus primeiros líderes e párocos, o Rev. Diogo Cassels, entre 1868 e 1923, e o Rev. António Ferreira Fiandor, desde a morte do primeiro até 1970, quer da importância da igreja e escola do Torne (AFONSO; SILVA; LACERDA, 2016), no contexto da IL e no meio social envolvente, uma vez que além das funções de igreja e escola acoplaram num mesmo complexo socioeducativo e religioso muitos outros dispositivos de dinâmica e interação social, como uma liga juvenil, uma sociedade mutualista, um bairro de habitação social, publicações diversas e muitos outros difíceis de descriminar (SILVA, 2018b) mas que geraram ao longo de século e meio intensa atividade e consequente produção documental.

Desta forma, as principais séries documentais são as respeitantes às atas da Junta Paroquial, normalmente conservadas na íntegra desde a fundação de cada comunidade. Em algumas paróquias subsistiram igualmente livros de atas das Comissões Cultuais, órgão de gestão administrativa imposto em 1911 pela Lei da Separação do Estado das Igrejas (Fig. 4). Estas séries, naturalmente prioritárias enquanto fonte de história institucional, conservam informações de muito interesse para o conhecimento dos protagonistas, eventos e da própria sociologia de cada congregação. 
Fig. 4 - Paróquia do Redentor, Porto. Livro de Atas da Comissão Cultual, 1911-1914.

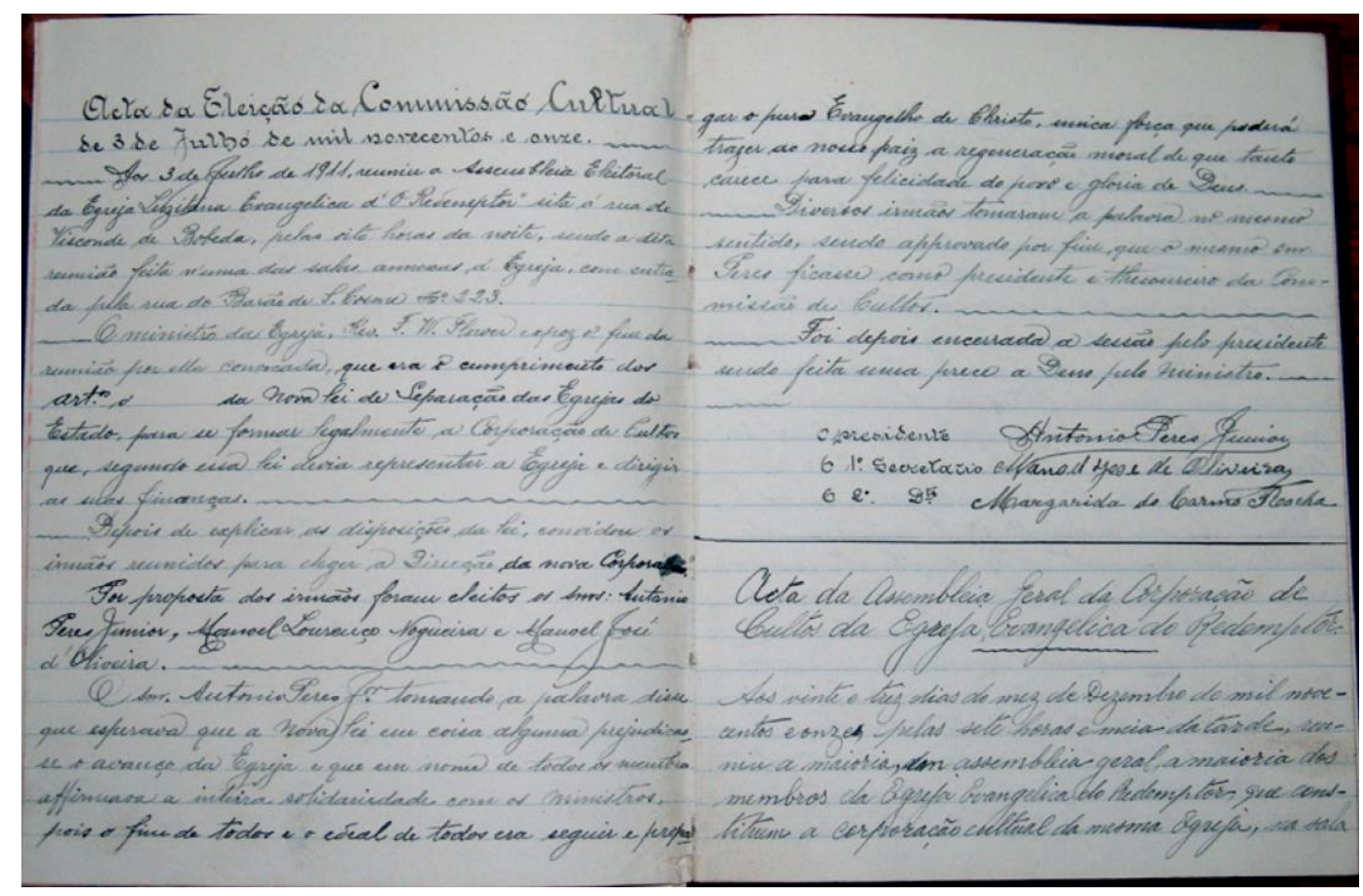

Fonte: Arquivo Paroquial do Redentor.

Outras séries fundamentais são as relacionadas com o registo dos serviços religiosos e especialmente com o "registo paroquial", ou seja, o assento dos atos de batismo, matrimónio e funeral, os mais antigos conservados no Torne desde 1874-1875. Existem também registos de "confirmações" 1897 (Redentor). Estes elementos são importantes para aferir a vivência das comunidades e o seu aro de atração social, se bem que se conservem, de forma mais irregular, listagens de membros, lista de contribuintes ao fundo paroquial e outra documentação similar.

A estrutura organizativa e pastoral de cada comunidade envolveu, além destas funções nucleares, todo um conjunto de dispositivos, muito variável em função das circunstâncias pessoais, históricas e locais, geradores de uma produção documental diversificada e globalmente de muito interesse, se bem que correntemente com séries temporalmente truncadas ou de curta duração. Referimo-nos por exemplo à documentação das Escolas Dominicais, Ligas Juvenis e de Esforço Cristão (VIDAL; AFONSO; SILVA, no prelo), Uniões Cristãs da Mocidade (desde 1898 no Redentor e 1906 na extinta missão da Madalena, Vila Nova de Gaia, Fig. 5), grupos de escoteiros e outras associações locais ou regionais dirigidas ao trabalho educativo, cultural e religioso com os jovens, como também aos registos de órgãos assistenciais ou mutualistas (por exemplo, no Torne, a Sociedade Evangélica de Socorros aos Pobres e Doentes, desde 1873) e comissões e grupos de trabalho da mais variada natureza. No âmbito mais estritamente pastoral, merecem destaque as séries e peças relativas aos diversos clérigos, quer as coleções de homilética (Fig. 6), quer muito em especial diversos diários que naturalmente cruzavam a vivência pessoal e familiar desses sacerdotes com a das comunidades a que assistiam (Fig. 7). Naturalmente, há também documentação relacionada com a gestão patrimonial, financeira e contabilística das paróquias, entre a qual diversos projetos de obras, concretizados ou não, bastante curiosos (Fig. 8).

${ }^{13}$ A Confirmação tem um sentido similar à comunhão solene ou profissão de fé na Igreja Católica Romana. Na Igreja Lusitana é o rito sacramental pelo qual, mediante a oração e a imposição das mãos do Bispo, o batizado recebe o poder do Espírito Santo e confirma pessoalmente, por livre consentimento, os compromissos antes assumidos pelos pais e padrinhos na ocasião do batismo. 
Fig. 5 - Missão da Madalena, V. N. Gaia. Relatório da União Cristã da Mocidade, 1907.

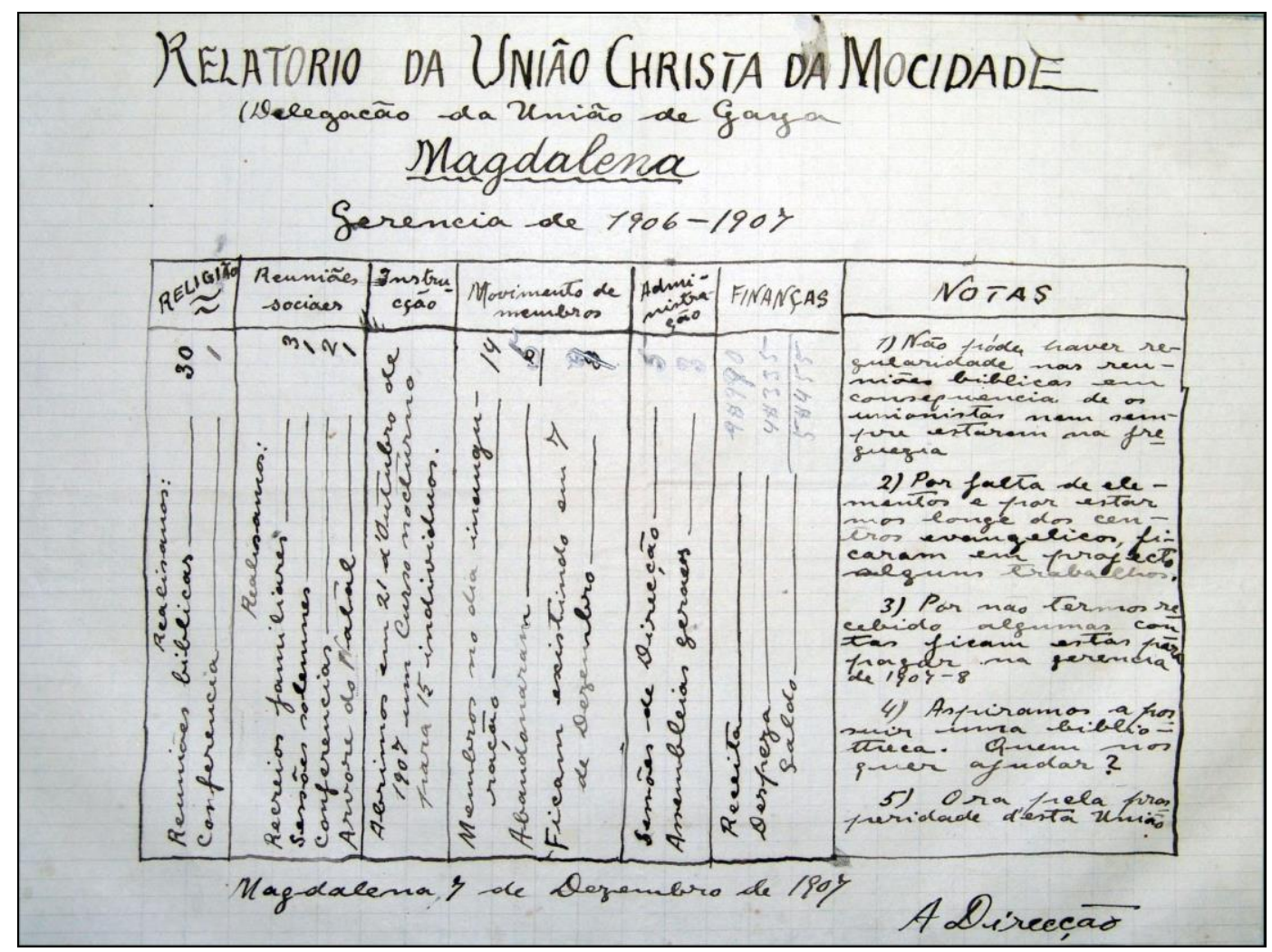

Fonte: Arquivo Paroquial do Salvador do Mundo.

Fig. 6 - Bispo D. António F. Fiandor. Apontamentos do primeiro Curso Teológico da Igreja Lusitana, 1904

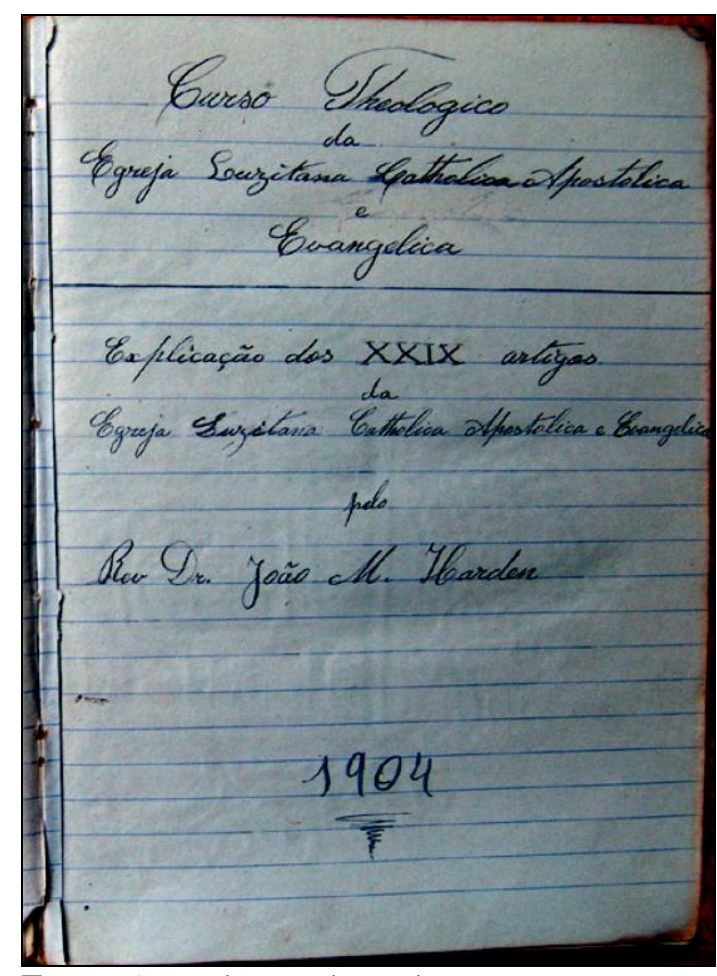

Fonte: Arq. Hist. Igreja Lusitana 
Fig. 7 - Paróquia do Redentor, Porto. Fotos de alunos da escola no diário do Rev. Frederick W. Flower. «Book nr. 2», 1930-1939.

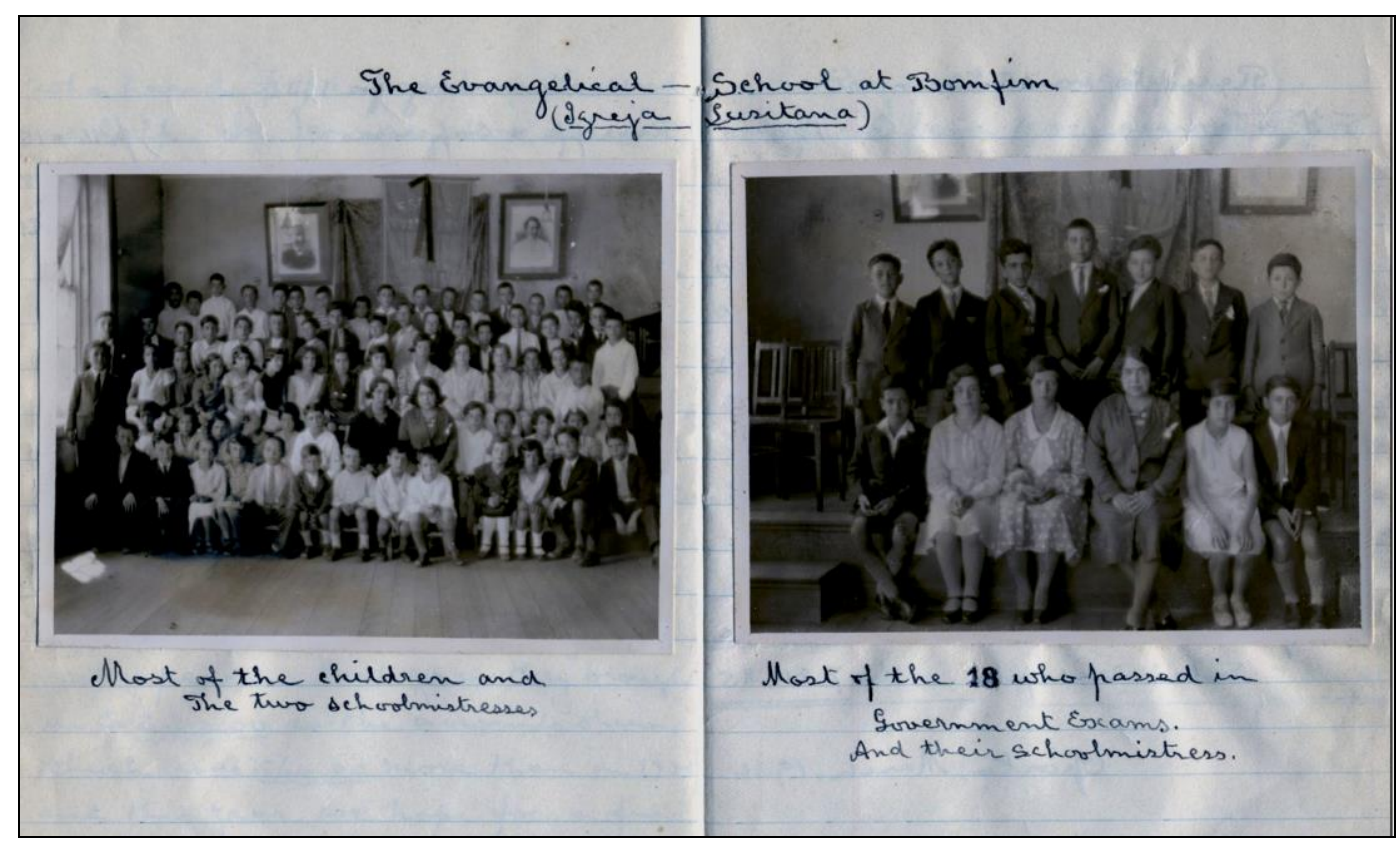

Fonte: Arquivo Paroquial do Redentor.

Fig. 8 - Paróquia do Salvador do Mundo, V. N. Gaia. Projeto da sede do "Esforço Cristão". Década de 1930.

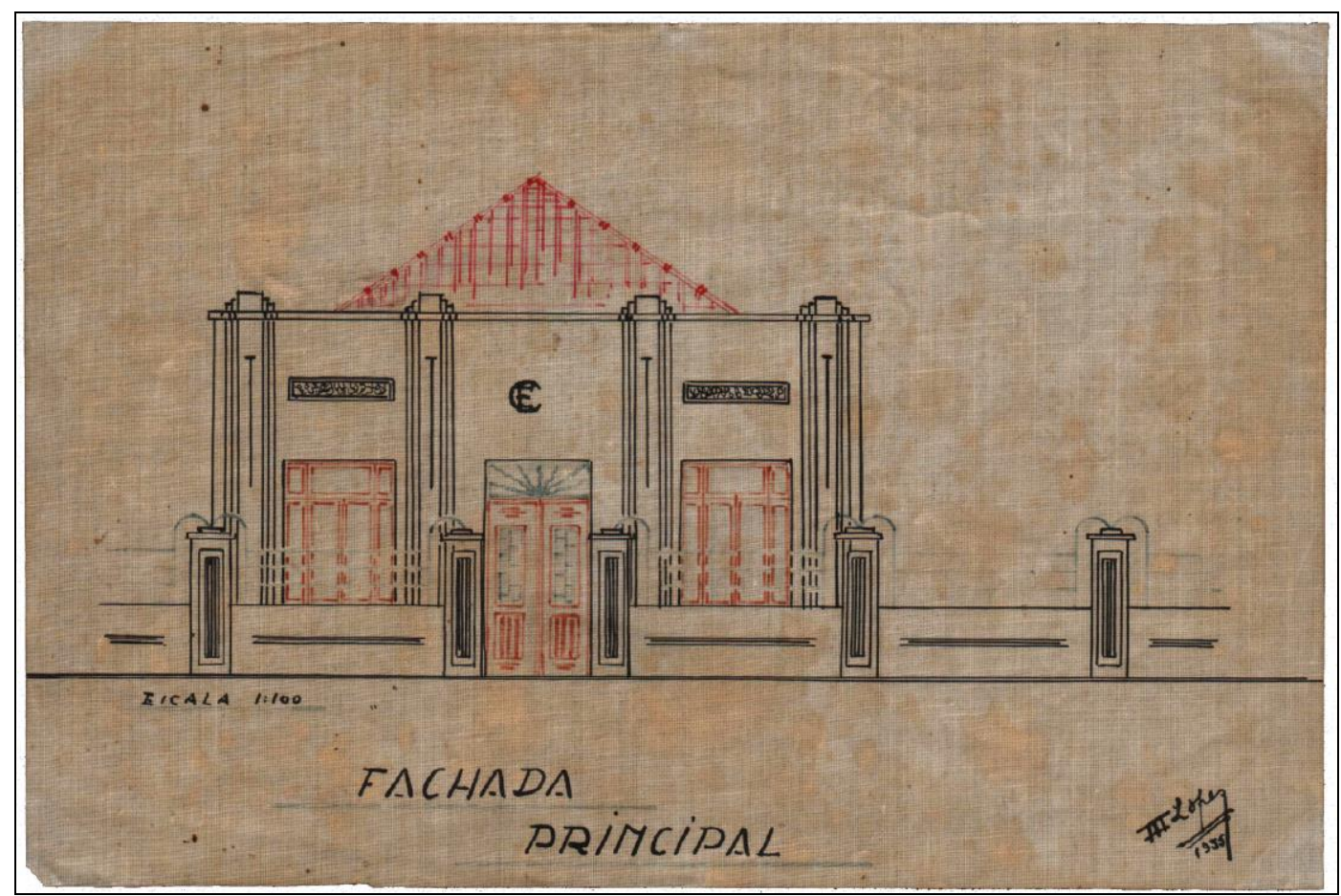

Fonte: Arquivo Paroquial do Salvador do Mundo.

Como a maior parte das paróquias tiveram originalmente associadas escolas de ensino elementar ou outros graus, para ambos os sexos, a documentação relacionada com estas constitui uma secção ou subfundo de particular interesse (AFONSO, 2011). Conservam-se em maior extensão e variedade os elementos das Escolas do Torne (fundada em 1868, mas com 
documentação a partir dos começos da década de 1880), Bom Pastor (1882, com registos desde 1918) e do Prado (1901), sendo muito lacunar ou quase inexistente a documentação das Escolas do Redentor (1887) ou Oliveira do Douro (1907) ${ }^{14}$. Nesta documentação sobressaem os registos de matrícula e frequência dos alunos (Fig. 9), objeto já de vários estudos quantitativos e sociológicos (AFONSO; LACERDA, 1995, 1996; AFONSO, LACERDA; SILVA, 2001; AFONSO, 2001a, 2004), registos contabilísticos (Fig. 10), mas há também memórias de professores (cfr. AFONSO, 2001b, acerca de um raro registo sonoro) e muitas outras atividades pedagógicas e de extensão educativa, como as festas escolares (AFONSO; SILVA, 2010, 2015), visitas de estudo, palestras, etc. Uma série muito curiosa, por exemplo, diz respeito aos "livros de benfeitores" das Escolas do Torne e do Prado, iniciados por Diogo Cassels em 1899 e que se prolongam, com variações de formulário, até à década de 1970, nos quais anualmente se inscreviam as entidades públicas ou privadas que concorriam para o sustento da escola (Figs. 11 e 12). Por estes cadernos, onde em cada ano Cassels anotava também estatísticas e outros dados de interesse da escola para consulta dos benfeitores, perpassa grande parte da vida económica de Vila Nova de Gaia e do Porto durante três quartos de século, com destaque para numerosas firmas ligadas ao Vinho do Porto, Bancos, indústrias e estabelecimentos comerciais, etc., permitindo aferir, por esta via, o impacte e relevância social daquelas instituições educativas (AFONSO, 2001a) ${ }^{15}$. Neste interface das instituições escolares da Igreja Lusitana com outras entidades administrativas, económicas ou sociais encontramos ainda, por exemplo, correspondência com diversas entidades oficiais ou documentação respeitante a uma importante organização do Estado Novo em Portugal, a Mocidade Portuguesa (no acervo de São João Evangelista, desde 1953).

Fig. 9 - Escola do Prado, V. N. Gaia. Registo de frequência dos alunos. 1915-1916.

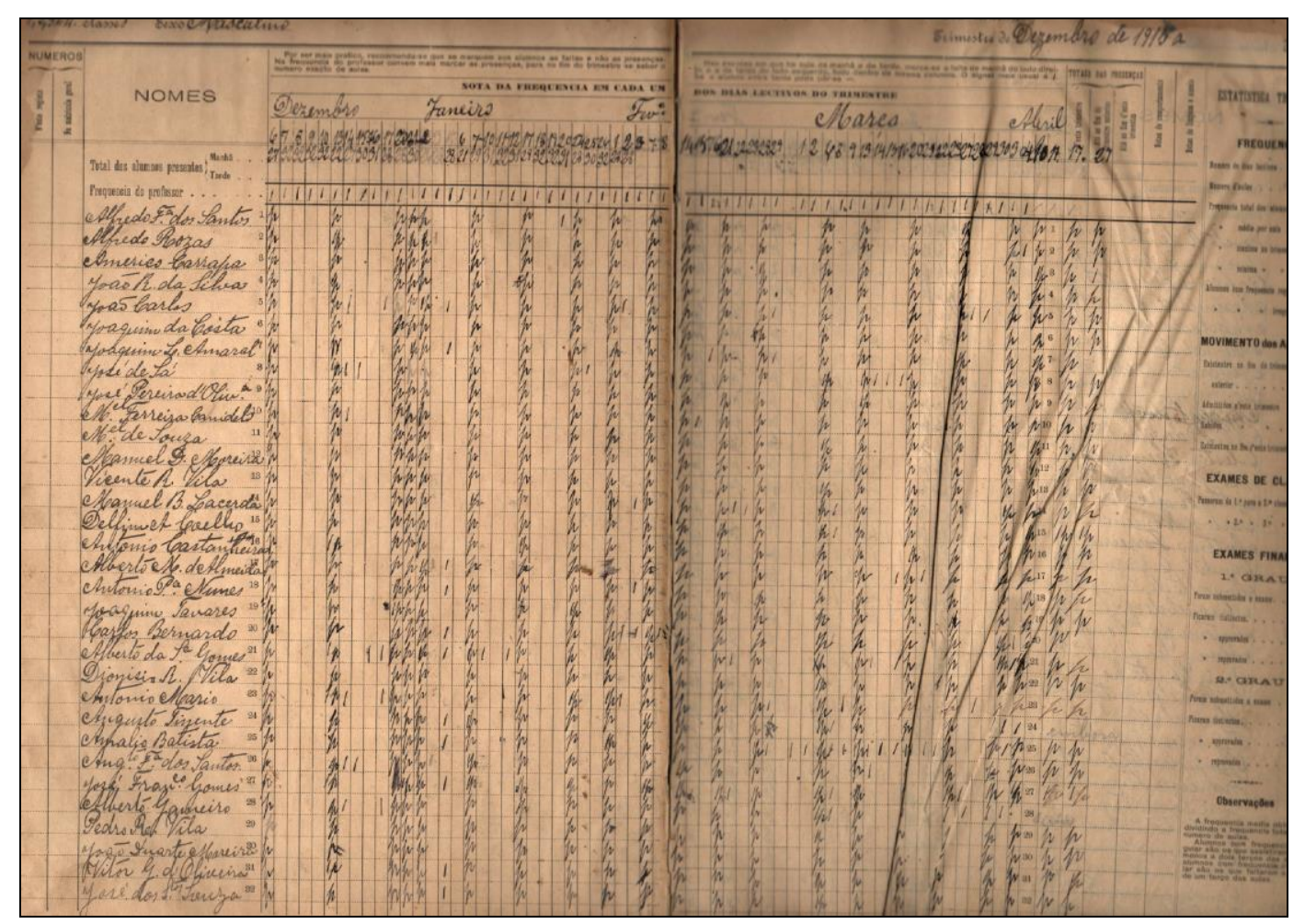

Fonte: Arquivo Paroquial do Salvador do Mundo.

\footnotetext{
${ }^{14}$ Para uma visão de conjunto da "rede escolar gaiense", ver SILVA; AFONSO, 2017.

15 Como referimos, esta série encontra-se entre as que foram reproduzidas e estão acessíveis quer na plataforma web do arquivo municipal de Vila Nova de Gaia, quer na do arquivo histórico da Igreja Lusitana.
} 
Fig. 10 - Escola do Bonfim, Porto. Registos de contas, 1930. «Book nr. 2», 1930-1939.

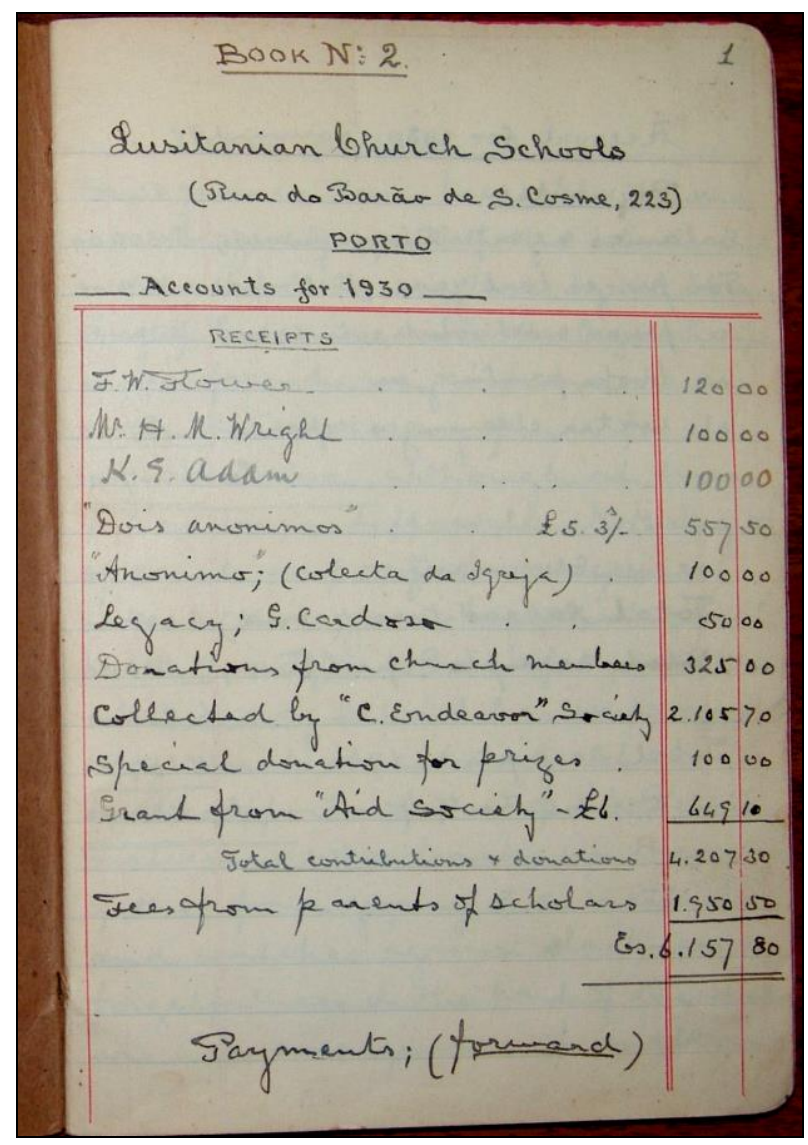

Fonte: Arquivo Paroquial do Redentor.

Fig. 11 - Escolas do Torne e do Prado, V. N. Gaia. «Livro dos Benfeitores», 1899.

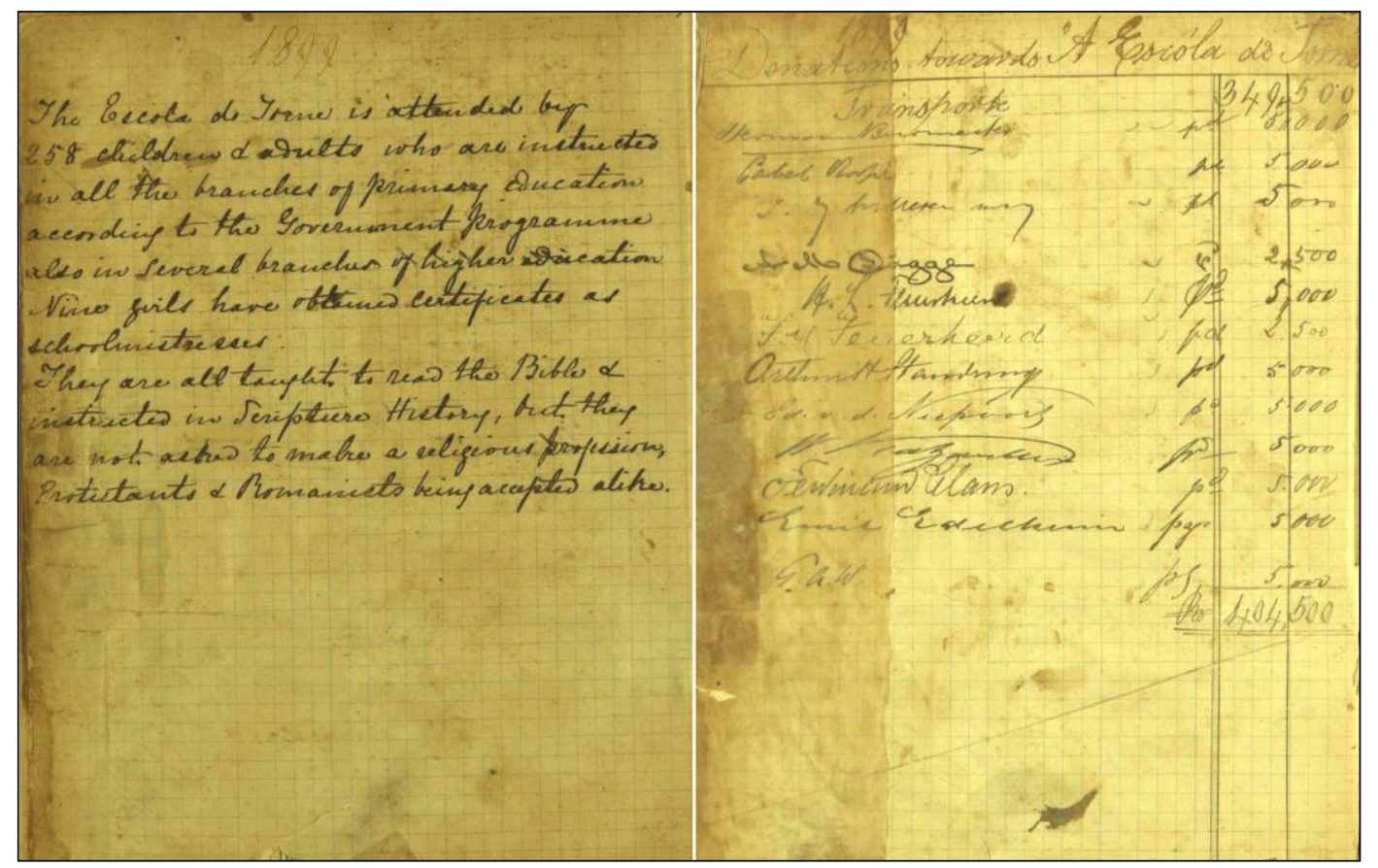

Fonte: Arq. Hist. Igreja Lusitana. 
Fig. 12 - Escolas do Torne e do Prado, V. N. Gaia. «Livro dos Benfeitores», 1930.

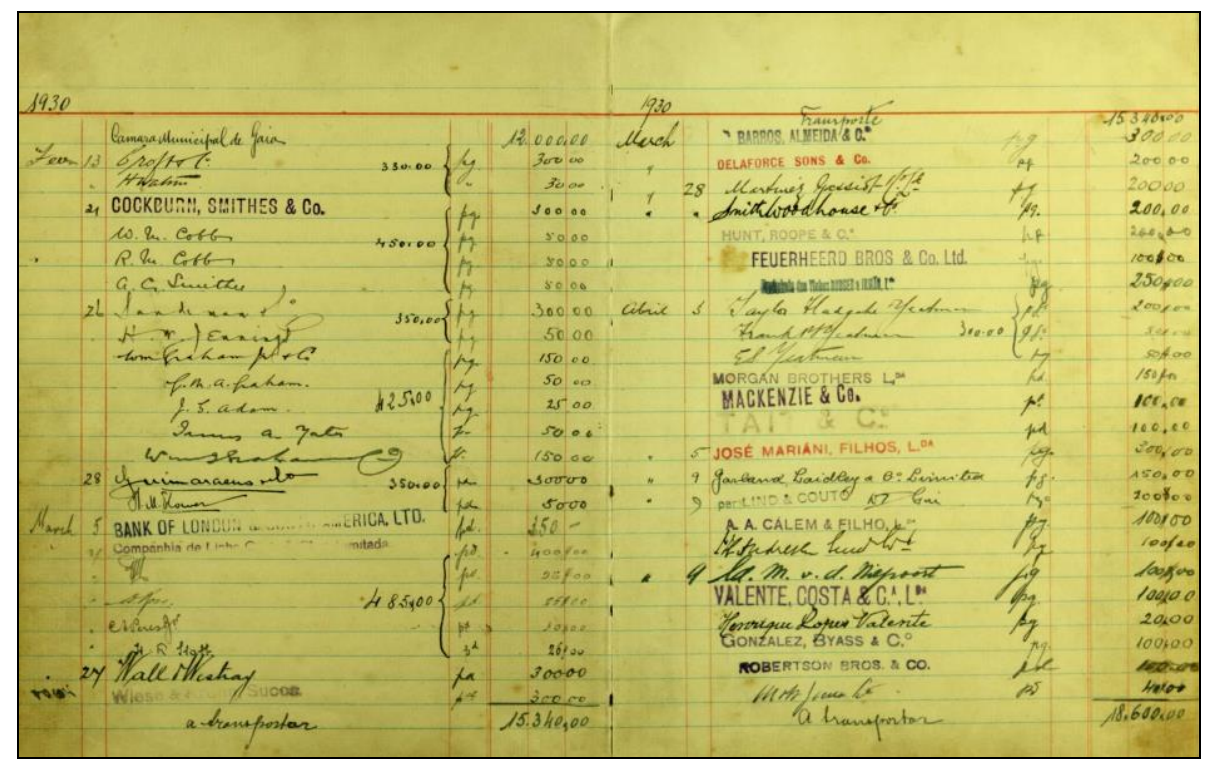

Fonte: Arq. Hist. Igreja Lusitana.

Integram ainda os arquivos lusitanos algumas coleções fotográficas, com vários milhares de espécimes, entre provas e negativos, e que remontará à década de 1880 . Encontrando-se o acervo mais significativo (arquivo original da paróquia de S. João Evangelista) já na sua maioria inventariado, trata-se agora de alargar esse trabalho às restantes coleções, quer a diocesana, quer as das outras comunidades (Fig. 13). Enquanto não lhes for dado o devido enquadramento museológico, também alguns objetos particulares caem no âmbito desta inventariação. Trata-se de uma coleção naturalmente heterogénea que inclui desde serviços de chá em faiança com a sigla da União Cristã da Mocidade do Bonfim (paróquia do Redentor), à caixa de lata onde se guardavam os fundos da Missão da Madalena, canetas e tinteiros de oferta a várias personalidades, estandartes das igrejas e escolas, as medalhas em prata oferecidas por Diogo Cassels aos melhores alunos, etc.

Fig. 13 - Paróquia do Redentor, Porto. Sala de aulas da União Cristã da Mocidade do Bonfim. Fotografia de começos do séc. XX.

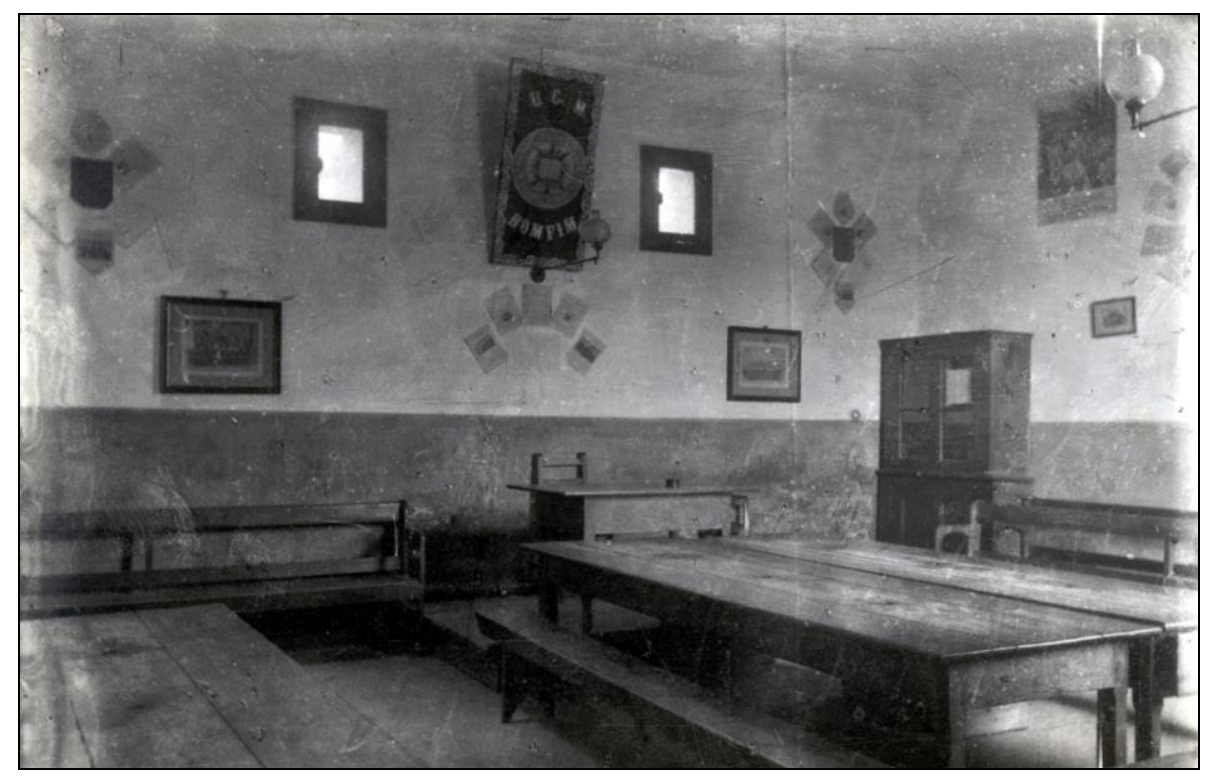

Fonte: Arquivo Paroquial do Redentor. 
No que designamos como «Biblioteca Histórica»e que está em tratamento e catalogação em processo paralelo ao dos Arquivos, atentas as diferentes especificidades metodológicas, inclui-se um conjunto de obras impressas essenciais para o entendimento da história e desenvolvimento da instituição e do protestantismo português, muitas delas exemplares únicos ou de grande raridade, como é o caso das séries completas ou bastante íntegras de diversas publicações periódicas. Nesta hemeroteca contam-se alguns dos primeiros jornais protestantes portugueses, como o Amigo da Infância (Lisboa-Porto, 18741940) e o já citado A Reforma (Porto, 1877-c.1897), para além do Egreja Lusitana (18921923), uma detalhada crónica da vida da igreja e escola do Torne que Diogo Cassels compilou ao longo das três décadas de publicação do jornal, ou ainda O Bom Pastor (19011922) (Fig. 14). Entre as obras de caráter geral merece também destaque uma extensa e diversificada coleção de edições bíblicas, remontando ao século XVIII e com exemplares em diversas línguas.

Fig. 14 - Primeiros números dos jornais A Reforma (Porto, 1877); Egreja Lusitana (V. N. Gaia, 1894) e O Bom Pastor (V. N. Gaia, 1901).

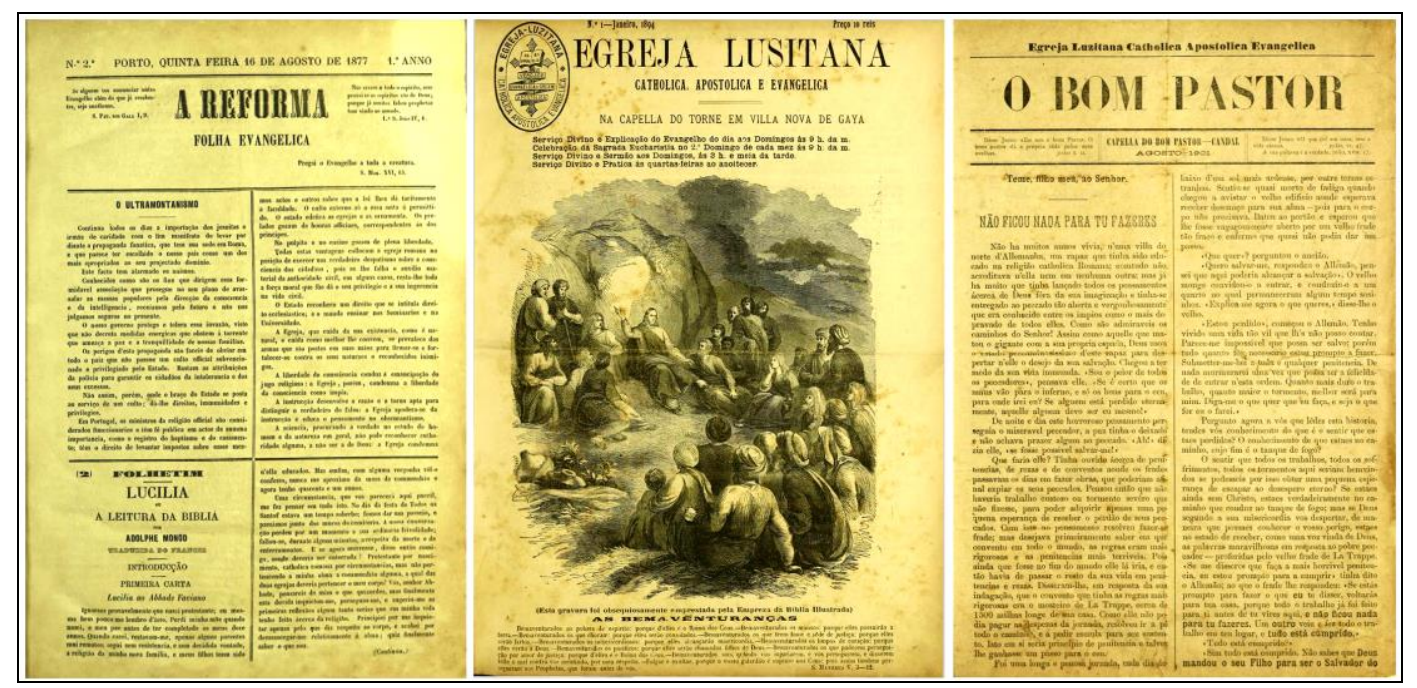

Fonte: Hemeroteca da Igreja Lusitana.

\subsection{Difusão e redes de conhecimento}

Potenciando a sua presença na web e o fomento de redes cooperativas de partilha de recursos e conhecimento, o Arquivo da Igreja Lusitana aderiu à Rede Portuguesa de Arquivos (RPA), levando a que o acervo já inventariado seja acessível também a partir do Portal Português de Arquivos (https://portal.arquivos.pt/), um agregador de conteúdos de informação arquivística (meta-informação e sempre que possível imagens) das entidades aderentes à RPA, permitindo, através de pesquisa a sua recuperação. Por esta via, o arquivo lusitano é igualmente acessível através do Portal Europeu de Arquivos (http://www.archivesportaleurope.net/).

O Arquivo da Igreja Lusitana integra ainda, a nível nacional, o RNOD, Registo Nacional de Objetos Digitais (http://rnod.bnportugal.pt/rnod/), um agregador de conteúdos nado-digitais e digitalizados disponibilizados em rede por entidades portuguesas que visa a coordenação e difusão desses recursos a nível nacional e internacional, designadamente através do conhecido portal «Europeana» (https://www.europeana.eu/portal/pt).

A monitorização da plataforma do Arquivo é feita, do ponto de vista técnico, por uma arquivista e um engenheiro informático, sendo essencial a colaboração de uma ampla rede de usuários para resolver bugs e outros problemas que ocorrem, e simultaneamente potenciar soluções inovadoras. O Arquivo está inserido na «comunidade AtoM» tanto a nível nacional 
como internacional (https://wiki.accesstomemory.org/Community/Users). No plano quantitativo e estatístico, conta-se essencialmente com as informações da ferramenta Google Analytics como forma de acompanhar a utilização e alcance do acervo documental.

Outras formas de difusão e partilha de informação têm sido ensaiadas, quer destinadas a um público científico, pela apresentação regular de comunicações em colóquios e fóruns técnicos, quer dirigidas naturalmente aos «clientes internos» que são os responsáveis e organizações da própria Igreja Lusitana, através da submissão de relatórios e apresentação de relatórios anuais ao sínodo, o órgão máximo da diocese nacional. No sítio oficial da Igreja (https://www.igreja-lusitana.org/) está regularmente informação sobre «O Documento em Destaque», um tema baseado numa qualquer efeméride ou assunto salientado, com hiperligação para o material original do acervo.

\section{Notas finais: regresso a uma igreja minoritária}

Reclamando-se herdeira de uma catolicidade primitiva, ortodoxa na fidelidade aos evangelhos e à tradição, mas ao mesmo tempo de forte inspiração bíblica e com uma liturgia formal que incorpora a simplicidade e a alegria do hinário protestante, a Igreja Lusitana pautou a sua atuação por um forte investimento na educação popular e na criação de dispositivos promotores do ensino, de estímulo ao livre pensamento e da socialização assente nos princípios cristãos mas também de uma cidadania consciente e interventiva.

Aproveitando a corrente nacionalista, o anticlericalismo e a associação generalizada da hierarquia e organização da igreja católica às estruturas decadentes da monarquia e do rotativismo político, a Igreja Lusitana ganhou respeito social e embalagem para nas vésperas da revolução de Outubro ousar propor-se aos portugueses como alternativa séria e credível à igreja dominante (SILVA, 1995a, 1998, 2011a, 2011b; LEITE, 2009), ambição que lograria escassos resultados mas que em nada beliscou o prestígio da acção social e educativa da IL ao longo do século XX.

Através de múltiplos dispositivos de ruptura, integração e recomposição social, como as escolas dominicais, as ligas juvenis, a imprensa e sobretudo a escolarização, incluindo creches, ensino elementar e educação de adultos, a Igreja Lusitana actuou numa lógica de redes a diferentes escalas geográficas, visando a promoção do indivíduo e através dele a regeneração social. Por estas circunstâncias muito particulares, a IL tem vindo a constituir-se nas últimas décadas em um importante case-study na historiografia do protestantismo português (AFONSO, 2000, 2009, 2013; LEITE, 2009; SILVA, 2011a).

$\mathrm{Na}$ verdade, o modelo que os protestantes portugueses foram implementando desde o início está estruturado em torno de princípios herdeiros de uma teologia liberal (TILLICH, 1992, p. 83, p. 229 sq.) que claramente fomentam um republicanismo cívico com alcance reformista nas dimensões moral e social, tendendo também eventualmente para esboçar uma posição política que defende, essencialmente, a constituição de sociedades progressistas e democráticas.

Esta posição é homóloga do modelo orgânico das comunidades protestantes onde se praticavam as regras do viver democrático, como aliás a estrutura da IL bem demonstra, a nível local como diocesano. Também se deverá enfatizar que esta lógica organizacional (comunidades pequenas, íntimas e autónomas) formava um ethos muito particular, já que, por um lado, fomentava um organicismo social cristão que se opunha ao individualismo conservador, e, por outro lado, demonstrava, no concreto, que a salvação não era só declinada como uma solução individual, mas devia ser, por essência, um processo de reforma moral bem mais amplo, concebido como a resposta que as comunidades - e por extensão os seus membros - davam aos problemas sociais, implicando uma concepção alargada de cidadania e, por consequência, uma prática democrática. 
Este ideal, em suma, motivou o processo de inserção dos protestantes na sociedade e alimentou sempre a materialização dos ideais, o que obviamente promoveu a aproximação às classes populares e aos seus problemas - do que o investimento na acção escolar e assistencial é cabal exemplo - e permitiu que as próprias comunidades reflectissem sobre a sua missão social (PIERSON, 1897).

De facto, um princípio basilar estruturou o protestantismo liberal: a questão social é uma questão ética (PEABODY, 1907, p. 116). Tal postulado levou a que nas comunidades se originassem níveis em que progressivamente se foram induzindo os princípios de que deveriam ser constituídas instituições capazes de suportar uma civilização moderna. Esses níveis - ou "círculos educativos" na terminologia de Florian Znaniecki (1988 [c.1940]) sairiam paulatinamente do âmbito da comunidade para se espraiarem pela sociedade envolvente, ou, dito de outra forma, deveriam começar no indivíduo para alcançarem o colectivo, ou seja, tinham implícita uma forte consciência do valor de cada um enquanto despoletador de dinâmicas de solidariedade.

Respondendo, portanto, aos desafios da sociedade - ou seja a preservação de um bem comum -, o processo de "reconstrução da regeneração individual como forma de brotar um mundo melhor" (PEABODY, 1907, p. 119), esteve sempre presente nas dinâmicas da generalidade das igrejas protestantes enquanto antropologia plural de fomentar uma educação integral do Homem. Todavia, a reforma social pressupõe que haja uma assunção de atitudes racionais e prudentes que pretendam resolver os problemas sem jamais olvidar que a perspectiva de que se parte para combater esse problema tem que ser justa, compreensiva e individualmente assumida ${ }^{16}$. Estabelece-se, portanto, uma hierarquia da acção social que, determinada pelas condições económicas (as quais, contudo, expressam um protesto moral), vai fomentando respostas nos campos da higiene, da economia social, da beneficência e da moral, fundamentalmente de uma moral pública (PEABODY, 1907, p. 90 sq.). Compreendese, então, que a progressiva externalização das propostas saia do âmbito das Igrejas para disseminar novos centros sociais, configurando um projecto moralizador, higienista e democrático que tem a doutrina como horizonte e a fé como princípio de acção ${ }^{17}$. Neste contexto, a educação é a base de todo o programa de reforma social que se quer implementar, ou demonstrar, como uma via possível de criação de uma sociedade moderna ( $c f$., VOELTZEL, 1960).

Todo este programa refletiu-se indelevelmente no protestantismo português e o modelo (com as suas diversas dimensões) foi ganhando solidez, ainda que acantonado aos espaços de influência das comunidades. Este modelo - naturalmente espelhado nas publicações e nos acervos documentais da IL e de outras igrejas protestantes - comportava uma dimensão de educação (científica, religiosa, social); uma dimensão associativa (com propósitos também de educação de adultos, formação profissional e educação religiosa); uma dimensão de formação teológica; uma dimensão assistencial (que admite iniciativas de âmbito meramente comunitário, mas que frequentemente alargavam o seu raio de acção); uma dimensão mutualista; e uma dimensão de temperança/regeneração (que implicou a participação também em iniciativas do campo reformador). Jean-Pierre Bastian (2001), aliás, levanta mesmo a hipótese de que a configuração associativa do protestantismo é essencial para se compreender um modelo de sociabilidade moderna:

\footnotetext{
${ }^{16}$ Ver Social Science: being Selections from John Cassell's Prize Essays by Working Men and Women. With Notes (1861), onde se defende o modelo que vai da auto-educação até à reforma sanitária, passando pela ocupação dos tempos livres, $c f$., Lawrence Goldman (2002).

17 Projecto que a figura de Diogo Cassels encarna de forma exemplar, como tem sido demonstrado (PEIXOTO, 2001, 2005; AFONSO, 2000).
} 
Puede parecer provocador afirmar que, en un contexto donde predominaba una cultura católica totalizadora que había estructurado mentalidades y prácticas sociales, los protestantismos no fueron ante todo un movimiento de ideas, sino más bien una forma de sociabilidad que podemos llamar moderna. Es a través de una forma asociativa que se difundieron ideas, modelos de gestión y una pedagogía en ruptura con la sociedad global. Afirmar el predominio del modelo organizativo sobre las ideas lleva a centrar el objeto no sobre la mera ideología, sino sobre el actor social mismo que se fue creando. (BASTIAN, 2001, p. 23).

De modo mais apurado, Bastian inventaria domínios a explorar e que no contexto ibérico são extremamente pertinentes, nomeadamente a interacção com as diferentes sociabilidades modernas, a pedagogia liberal difundida pela sociabilidade e o significado da dissidência religiosa. Nota, também, que o universo dos actores protestantes é global e que por esta circunstância eles são protagonistas multifacetados, sendo a sua acção vital (num tempo crucial de regeneração do sujeito social como se apresentava o século XIX, nomeadamente pela interferência entre o social e o político) ilustrada pelos temas reivindicados pelos protestantes e outros movimentos sociais e políticos, levando aquele mesmo autor a sintetizar que "la afinidad electiva entre protestantismo y liberalismo conduce necesariamente a plantearnos el tipo de liberalismo difundido por las organizaciones protestantes." (BASTIAN, 2001, p. 28).

Deste modo, entendemos que o tratamento, organização e catalogação dos fundos arquivísticos da Igreja Lusitana, a par da sua importante hemeroteca e biblioteca histórica, para além do interesse institucional que naturalmente comporta, assume fulcral relevância para o estudo e compreensão do papel das minorias religiosas na construção da modernidade, como memória e cultura, produtoras de subjectividades, que protagonizam um agir colectivo essencial no processo de secularização da sociedade portuguesa.

\section{Referências}

ABREU, Maria Zina G.. Implantação da Fé Protestante na Ilha da Madeira. Perspectiva Cultural do Proselitismo de Roberto Reid Kalley: 1838 - c. 1846. Revista Islenha, Funchal, 29, p. 79-101, 2011.

AFONSO, José António. O projecto de Diogo Cassels: contributo para o estudo da educação popular. In: VEIGA, M. A. \& MAGALHÃES, J. (Orgs.). Homenagem ao Prof. Dr. José Ribeiro Dias. Braga: IEP/Universidade do Minho, 2000, p. 309-323.

AFONSO, José António. Iniciativas evangélicas de educação popular: reflexões sobre a Escola do Torne (Vila Nova de Gaia). Anales de Historia Contemporânea, Múrcia, 17, p. 415-434, 2001a.

AFONSO, José António (2001b). Modos de socialização numa comunidade evangélica: memórias de uma professora da Escola do Torne. In: RAMOS, L. O. ; JORGE, M. R. \& POLÓNIA, A. (Coord.). Estudos em homenagem a João Francisco Marques. Vol. 1. Porto: Faculdade de Letras - Universidade do Porto, 2001 b, p. 49-55. 
AFONSO, José António. A construção de uma escola protestante: o caso da Escola do Torne (Vila Nova de Gaia), 1883-1923. In: FERREIRA, A. G. (Org.). Escola, Culturas e Identidades - Comunicações do $3^{\circ}$ Congresso Luso-Brasileiro de História da Educação. Vol. 2. Coimbra: Sociedade Portuguesa Ciências Educação,2004, p. 62-65.

AFONSO, José António. Protestantismo e Educação. História de um projecto pedagógico alternativo em Portugal na transição do séc. XIX. Braga: Universidade do Minho/Instituto de Educação e Psicologia, 2009.

AFONSO, José António. Escolas protestantes: dispositivos de inserção e de regeneração. Uma reflexão sobre a realidade portuguesa de meados do século XIX até às primeiras décadas do século XX. In: FEREIRA, A. M. \& ALMEIDA, J. M. (Coord.), Religião e Cidadania. Protagonistas, motivações e dinâmicas sociais no contexto ibérico. Lisboa: Universidade Católica Portuguesa, 2011, p. 547-565.

AFONSO, José António. A Igreja Lusitana Católica Apostólica Evangélica (ILCAE) - das encruzilhadas sociojurídicas à afirmação de uma identidade religiosa. In: Pintassilgo, Joaquim (Coord.). Laicidade, Religiões e Educação na Europa do Sul no Século XX. Lisboa: Instituto de Educação da Universidade de Lisboa, 2013, p. 73-109.

AFONSO, José António. As representações da infância e da juventude na imprensa infantojuvenil protestante portuguesa na transição do séc. XIX: Uma leitura do Amigo da Infância (1874 - 1940). In: MORAIS, J. J. et alii (Orgs.), Secularidades \& Confessionalidades na História da Educação Contemporânea. João Pessoa: Sal da Terra, 2014, p.87-106.

AFONSO, José António; LACERDA, Silvestre Almeida. Memórias da Escola do Torne. In: Actas do Colóquio Vila Nova de Gaia de há 100 anos. Colóquio comemorativo do centenário da Igreja do Torne. V. N. Gaia: Junta Paroquial São João Evangelista,1995, p. 169-223.

AFONSO, José António; LACERDA, Silvestre Almeida. Esplendor de uma escola. Subsídios para o estudo da Escola do Torne (1894-1923). Boletim da Associação Cultural Amigos de Gaia, V. N. Gaia, 42, p. 27-47,1996.

AFONSO, José António; LACERDA, Silvestre Almeida; SILVA, António Manuel S. P.. A população escolar feminina de Sta. Marinha na Escola do Torne na transição do séc. XIX para o séc. XX. Notas exploratórias. In: $\mathbf{1}^{\text {as }}$. Jornadas de História Local de Santa Marinha. Vila Nova de Gaia: Junta Freguesia de Santa Marinha, 2001, p. 159-172.

AFONSO, José António; SILVA, António Manuel S. P.. Momentos da imprensa infantojuvenil protestante em Portugal: O Amigo da Infância (1874-1940) e o Raio de Sol (19251951) - Aproximações às dinâmicas e ciclos do movimento evangélico. In: CASTILLO GÓMEZ, A. (Dir.); SIERRA BLAS, V. (Ed.). Mis primeros pasos. Alfabetización, escuela y usos cotidianos de la escritura (siglos XIX y XX). Gijón: Trea, 2008, p. 95-122.

AFONSO, José António; SILVA, António Manuel S. P.. Cultura escolar e representação. As Festas da Escola do Torne (Vila Nova de Gaia) durante o ciclo de Diogo Cassels (1868-1923). In: FELGUEIRAS, M. L. \& VIEIRA, C. E. (Dir.). Cultura escolar, migrações e cidadania: actas do Congresso Luso-Brasileiro de História da Educação, 7, 2008 [CD-ROM]. Porto: Sociedade Portuguesa de Ciências da Educação, 2010. 
AFONSO, José António; SILVA, António Manuel S. P.. A Escola do Torne (Vila Nova de Gaia, Portugal, 1883-1922):As festas escolares como práticas educativas. In: STAMATTO, M. I. S. \& NETO, O. M. M. (Orgs.). Práticas Educativas, Formação e Memória. Campinas, S. P.: Mercado das Letras, 2015, p. 15-62.

AFONSO, José António; SILVA, António Manuel S. P. \& LACERDA, Silvestre Almeida (2016). A escola do Torne (Vila Nova de Gaia): dinâmicas socioeducativas de uma escola evangélica na transição do século XIX para o século XX. In: VIEIRA, Cesar Romero Amaral \& VILAS-BÔAS, Ester Fraga (Orgs.). Contribuições do protestantismo para a história da educação no Brasil e em Portugal. Piracicaba, SP: UNIMEP - Universidade Metodista de Piracicaba, 2016, p. 39-60.

AFONSO, José António; SILVA, António Manuel S. P.; LACERDA, Silvestre Almeida \& PEIXOTO, Fernando. Angel Herreros de Mora: um expoente da convergência ibérica na implantação do anglicanismo peninsular. Anales de Historia Contemporánea, Múrcia, 21, p. 383-408, 2005.

ASPEY, Albert. Por este caminho. Origem e progresso do Metodismo em Portugal no Século XIX. Umas páginas da história da procura da liberdade religiosa. Porto: Igreja Evangélica Metodista em Portugal, 1971.

BARRETO, José Maria. Introdução da Reforma em Portugal. Extracto da Conferência realizada na União Christã Evangélica da Mocidade Portuguesa em 23 de Fevereiro de 1901. Lisboa: [S. Ed.], 1901.

BASTIAN, Jean-Pierre. Problemas y métodos para la investigación de los protestantismos ibéricos del siglo XIX y XX. Anales de Historia Contemporânea, Múrcia, 17, p. 21-34, 2001.

BOULAY, Béremger. Variations d'échelle: cartographie, historiographie, narratologie . ATALA, Rennes, 13: Le Royaume-Uni : culture et identités, p. 285-300, 2010.

CARDOSO, Manuel P.. História do Protestantismo em Portugal. Figueira da Foz: Centro Ecuménico Reconciliação, 1985.

CARDOSO, Manuel P.. Protestantismo em Portugal. ICALP. Revista, Lisboa, 18, p. 141149, 1989.

CARDOSO, Manuel P.. Por Vilas e Cidades. Notas para a história do protestantismo em Portugal. Lisboa: Seminário Evangélico de Teologia, 1998.

[CASSELS, Diogo]. A Reforma em Portugal. A historia resumida já publicada na "Egreja Lusitana" nos annos de 1897 e 1898, revista, augmentada... .Porto: Typ. a Vapor de José da Silva Mendonça, 1908 [Reedição: V. N. Gaia: /estratégias cristivas/Igreja Lusitana, 2018].

CÊ, Graziella; FLORES, Daniel. O conceito e a aplicabilidade do ica-atom (atom) como ferramenta de descrição, difusão e acesso do patrimônio documental arquivístico. Informatio, Montevidéu, 21(2), p. 88-100, 2016. 
CIRNE, Teresa; VIDAL, Alexandra; SILVA, António Manuel S. P.; AFONSO, José A. Cooperação arquivística entre o Município de Gaia e a Igreja Lusitana: um exemplo de partilha integrada de interesse público. In: Actas. Congresso Nacional de Bibliotecários, Arquivistas e Documentalistas. 13 [Em linha: www.bad.pt/publicacoes], 6 pp. não numeradas, 2018.

COSTA, Maria Zita Freire Amado Ferreira da. Retrato de uma minoria religiosa em Portugal. Os registos da Igreja Metodista do Mirante, Porto, 1878-1978. 2 Vols. Dissertação de Mestrado, texto policopiado. Porto: Faculdade de Letras da Universidade do Porto, 1997.

Des protestantismes en "lusophonie catholique". Lusotopie 1998. Paris/Talence, 1998.

DESCAMPS, Florence. L'historien, l'archiviste et le magnétophone. De la constitution de la source orale à son exploitation. Paris: Comité pour l'histoire économique et financière de la France, 2001.

Dynamiques religieuses en lusophonie contemporaine. Lusotopie 1999. Paris/Talence, 1999.

FERNANDES, Ferreira. Madeirenses errantes. Lisboa: Oficina do Livro, 2004.

FIGUEIREDO, J. Santos. Factos notaveis da Historia da Egreja Lusitana. $2^{\text {a }}$ ed. "Biblioteca Antonio Maria Candal". 2a série. 2. [1 $1^{\mathrm{a}}$ ed. de 1909, na mesma colecção]. Porto: Typ. Mendonça, 1910.

GOLDMAN, Lawrence. Science, Reform and Politics in Victorian Britain: The Social Science Association, 1857-1886. Cambridge: Cambridge University Press, 2002. https://doi.org/10.1017/CBO9780511490545

GUICHARD, François. Le Protestantisme au Portugal. Arquivos do Centro Cultural Português, Paris, 28, p. 455-482, 1990.

GUICHARD, François. (1993a) - Madère, pôle de diffusion du protestantisme dans le monde lusophone. In: Missionação Portuguesa e Encontro de Culturas. Actas do Congresso Internacional de história. Braga: Universidade Católica Portuguesa, vol. 4, 1993 a, p. 157-171.

GUICHARD, François. La place de la Madère dans 1'histoire du protestantisme lusophone (XIXe-XXe siècles). In: Actas do $3^{\circ}$ Colóquio Internacional de Historia da Madeira. Funchal: Centro de Estudos de História do Atlântico,1993 b, p. 585-595.

GUICHARD, François. A formação de um protestantismo Lusófono através do Atlântico: esquema de difusão. Revista da Faculdade de Letras - História, Porto, $2^{a}$ Série, 12, p. 411 429, 1995 a.

GUICHARD, François. O Torne e a Igreja Lusitana no contexto do Protestantismo português do séc. XIX. In: Vila Nova de Gaia de há 100 anos. Colóquio comemorativo do centenário da igreja do Torne. Actas. V. N. Gaia: Junta Paroquial de São João Evangelista,1995 b, p. 57-69.

KALLEY, Robert R.. Exposição de Factos relativos à agressão contra os protestantes na Ilha da Madeira. Ed. original: Funchal, 1843. Lisboa: [S. Ed.], 1875. 
LEITE, Rita Mendonça. Protestantismo e Republicanismo: o percurso de Eduardo Moreira, protestante e membro do Partido Republicano Português. Lusitania Sacra, Lisboa, $2^{a}$ série, 19-20, p. 91-119, 2007-2008.

LEITE, Rita Mendonça. Representações do Protestantismo na Sociedade Portuguesa Contemporânea. Da exclusão à liberdade de culto (1852-1911). Lisboa: Centro de Estudos de História Religiosa - Universidade Católica, 2009.

LEITE, Rita Mendonça. Eduardo Moreira e as missões protestantes no espaço colonial português: ecos de um projeto pedagógico de evangelização na primeira metade do século XX. Lusitania Sacra, Lisboa, $2^{\mathrm{a}}$ série, 25, p. 115-125, 2012.

LEITE, Rita Mendonça. Texto e Autoridade. Diversificação sociocultural e religiosa com a Sociedade Bíblica em Portugal (1804-1940). 2 Vols. Tese de Doutoramento, texto policopiado. Lisboa: Faculdade de Letras da Universidade de Lisboa, 2016.

LEPETIT, Bernard. L'histoire prend-t-elle les acteurs au sérieux?. Espaces Temps, Lausanne, 59-61: Le temps réfléchi. L'histoire au risque des historiens, p. 112-122,1995.

LOPES, Rosa M. Barros. Valdosende: origem de uma minoria protestante. Dissertação de Mestrado, texto policopiado. Porto: Faculdade de Letras da Universidade do Porto, 2001.

MARQUES, João Francisco. Para a história do Protestantismo em Portugal. Revista da Faculdade de Letras - História, Porto, $2^{a}$ Série, 12, p. 431-475, 1995.

MARQUES, João Francisco. A controvérsia doutrinária entre o catolicismo e o protestantismo em Portugal no último quartel do século XIX. Lusotopie 1998 - Des protestantismes en "lusophonie catholique", Paris/Talence, p. 283-298, 1998.

MARQUES, João Francisco; GUICHARD, François. Programme de travail sur les minorités religieuses et de pensée au Portugal et notamment le cas du protestantisme. Lusitania Sacra, Lisboa, $2^{a}$ Série, 8/9, p. 599-609, 1996-1997.

Minorías Religiosas en España y Portugal, ayer y hoy. Anales de Historia Contemporánea, Murcia, 17, 2001.

MOREIRA, Eduardo H.. Notas históricas sobre a origem das Igrejas Evangélicas em Portugal. Separata da "Revista de História". Braga: [Ed. A.], 1913.

MOREIRA, Eduardo. Esboço da História da Igreja Lusitana. S. 1. [Vila Nova de Gaia]: Igreja Lusitana Católica Apostólica Evangélica, 1949.

MOREIRA, Eduardo. Crisóstomo Português. Elementos para a História do Púlpito. [Lisboa]: Junta Presbiteriana de Cooperação em Portugal, 1957.

MOREIRA, Eduardo. Vidas Convergentes. História breve dos movimentos de reforma cristã em Portugal a partir do século XVIII. [Lisboa]: Junta Presbiteriana de Cooperação em Portugal, 1958. 
MOREIRA, J. M. Mendes. Origens do Episcopalismo em Portugal - O despertar da Igreja Lusitana (1839-1899). 2 Vols. Dissertação de Mestrado, texto policopiado. Porto: Faculdade de Letras da Universidade do Porto, 1995.

MOREIRA, Joaquim M. Mendes. Em busca da identidade: de uma igreja minoritária de finais de Oitocentos - o caso da Igreja Lusitana Católica Apostólica Evangélica. In: RAMOS, L. O.; JORGE, M. R. \& POLÓNIA, A. (Coord.). Estudos em homenagem a João Francisco Marques. Vol. 2. Porto: Faculdade de Letras - Universidade do Porto, 2002 p. 175-84.

NEMÉSIO, Maria Inês. Índices de livros proibidos no século XVI em Portugal: à procura da 'Literatura'. Comunicação apresentada ao I Encontro do Grupo de Estudos Lusófonos, Porto, Faculdade de Letras, setembro, 2011. Disponível em http:// web.letras.up.pt/gel/I\%20Encontro/Maria\%20In\%C3\%AAs\%20Nem\%C3\%A9sio.pdf [consulta em 18.12.2017].

NETO, Vítor. O Estado, a Igreja e a Sociedade em Portugal (1832-1911). Lisboa: IN-CM, 1998.

Nos 200 Anos da Sociedade Bíblica. Revista Lusófona de Ciência das Religiões, Lisboa, 4, 7-8, 2005.

O Protestantismo no espaço lusófono. Revista Lusófona de Ciência das Religiões, Lisboa, 5, 9-10, 2006.

OLIVEIRA, Narciso de. Alfredo Henrique da Silva. Evangelizador de acção e cristão do mundo. Dissertação de Mestrado, texto policopiado. Porto: Faculdade de Letras da Universidade do Porto, 1996.

PEABODY, Francis Greenwood. Jesus Christ and the Social Question. An Examination of the Teaching of Jesus in its Relation to some of the Problems of Modern Social Life. $1^{\mathrm{a}}$ ed.: 1900. London: Macmillon and C ${ }^{\circ}$, Limited, 1907.

PEIXOTO, Fernando. Diogo Cassels, uma vida em duas margens. 2 Vols. Dissertação de Mestrado, texto policopiado. Porto: Faculdade de Letras da Universidade do Porto, 1995 a.

PEIXOTO, Fernando. A dívida do Protestantismo aos Cassels. In: Vila Nova de Gaia de há 100 anos. Colóquio comemorativo do centenário da igreja do Torne. Actas. V. N. Gaia: Junta Paroquial de São João Evangelista, 1995 b, p. 35-56.

PEIXOTO, Fernando. O que se sabe e o que se procura sobre o protestantismo em Portugal. Lusotopie 1999 - Dynamiques religieuses en lusophonie contemporaine. Paris/Talence, p. 257-269, 1999.

PEIXOTO, Fernando. Diogo Cassels, uma vida em duas margens. V. N. Gaia: Câmara Municipal, 2001.

PEIXOTO, Fernando. Diogo Cassels. A Praxis ao serviço da Fé. Vila Nova de Gaia: estratégias criativas, 2005.

PIERSON, Arthur T.. L'Évangelisation. Principes et Pratiques. Genève: L’Adresse Office, 1897. 
Protestantismo e Catolicismo nos séculos XIX e XX. Lusitania Sacra, Lisboa, $2^{\text {a }}$ Série. 11, 1999.

RIBEIRO, Eduardo; RIBEIRO, Joel. Precursores da Reforma em Portugal. Queluz: Núcleo, 2001.

SANTOS, Luís Aguiar. A primeira geração da Igreja Lusitana Católica Apostólica Evangélica (1876-1902). Lusitania Sacra, Lisboa, 2ª Série, 8-9, p. 299-360, 1996-1997.

SANTOS, Luís Aguiar. O protestantismo em Portugal (séculos XIX e XX): linhas da sua história e historiografia. Anales de Historia Contemporánea, Múrcia, 17, p. 53-76, 2001.

SANTOS, Luís Aguiar. (2002). A transformação do campo religioso português. In: AZEVEDO, Carlos M. (Dir.). História Religiosa de Portugal. Vol. 3. Lisboa: Círculo de Leitores/Universidade. Católica Portuguesa, 2002, p. 419-491.

SILVA, António Manuel S. P.. A Igreja Lusitana e o Republicanismo (1880-1910): Convergências e Expectativas do Discurso Ideológico. In: SANTOS, M. H. Carvalho (Coord.). A Vida da República Portuguesa 1890-1990. Vol. 2. Lisboa: Cooperativa de Estudos e Documentação,1995 a, p. 739-756.

SILVA, António Manuel S. P.. Dos prelos como instrumento de missão. A "boa imprensa" e a imprensa protestante no último quartel do século XIX. In: Vila Nova de Gaia de há 100 anos. Colóquio comemorativo do centenário da igreja do Torne. Actas. V. N. Gaia: Junta Paroquial de São João Evangelista, 1995 b, p. 93-130

SILVA, António Manuel S. P.. Os protestante e a política portuguesa. O caso da Igreja Lusitana na transição do séc. XIX para o séc. XX. Lusotopie 1998 - Des protestantismes en "lusophonie catholique", Paris/Talence, p. 269-282, 1998.

SILVA, António Manuel S. P.. (2005) - A Reforma, o primeiro jornal evangélico português. Revista de Portugal, Vila Nova de Gaia, 2, p. 60-71, 2005.

SILVA, António Manuel S. P.. Compromisso cristão e intervenção política nas primeiras gerações protestantes em Portugal: o caso da Igreja Lusitana. In: FERREIRA, A. M. \& ALMEIDA, J. (Coord.). Religião e Cidadania. Protagonistas, motivações e dinâmicas sociais no contexto ibérico. Lisboa: Universidade Católica Portuguesa, 2011 a, p. 567-592.

SILVA, António Manuel S. P.. O protestantismo português e a República: da utopia à realidade. In: Igreja e República(s): Mito(s) e História(s). Actas do $6^{\circ}$ Encontro Cultural de São Cristóvão de Lafões. Lafões: Associação dos Amigos do Mosteiro de São Cristóvão de Lafões, 2011 b, p. 47-72.

SILVA, António Manuel S. P., (Coord.). Paróquia de Cristo e Colégio Evangélico Lusitano: um século de testemunho cristão em Oliveira do Douro (V. N. Gaia). Vila Nova de Gaia: Igreja Lusitana Católica Apostólica Evangélica, 2013.

SILVA, António Manuel S. P.. O protestantismo em Albergaria-a-Velha. Um metodista no Palhal há 160 anos. Albergue. História e Património do Concelho de Albergaria-a-Velha, Albergaria-a-Velha,3, p. 33-52, 2016. 
SILVA, António Manuel S. P. (no prelo) - A reforma protestante em Portugal. Dos percursores aos finais da monarquia. In: AA. VV., A Reforma aos 500 anos (1517-2017). Porto: Fundação SPES, 2018 a, p. 175-249.

SILVA, António Manuel S. P.. Torne (1868-2018): um lugar na História. V. N. Gaia: Paróquia Lusitana de São João Evangelista; Assoc. das Escolas do Torne e do Prado, 2018 b.

SILVA, António Manuel S. P.; AFONSO, José António. Associação das Escolas do Torne e do Prado: servir, educar e incluir. V. N. Gaia: AETP, 2015.

SILVA, António Manuel S. P.; AFONSO, José António. A rede escolar protestante em Vila Nova de Gaia (1868-1923): uma panorâmica geral. In: RIBEIRO, Cláudia P. \& ARAÚJO, Francisco M. (Orgs.). A História da Educação em Vila Nova de Gaia. Porto: CITCEM/ FLUP, 2017, p. 25-62

SILVA, António Manuel S. P.; AFONSO, José António \& VIDAL, Alexandra. (2016) - A Igreja e a Escola do Prado: cento e quinze anos de instrução e testemunho cristão em Coimbrões, Vila Nova de Gaia. V. N. Gaia: Igreja Lusitana Católica Apostólica Evangélica, 2016.

Social Science: being Selections from John Cassell's Prize Essays by Working Men and Women. With Notes. London: Cassell, Peter and Galpin/La Belle Sauvage Yard, 1861.

TESTA, Michael P.. O Apóstolo da Madeira. Lisboa: Igreja Evangélica Presbiteriana de Portugal,1963.

TILLICH, Paul. A Era Protestante. S. Paulo: Instituto Ecuménico de Pós-Graduação em Ciências da Religião, 1992.

VAN DER GRIJP, Klaus. Recent research to the history of Protestantism in Spain and Portugal. Exchange, Leiden, 28, 2, p. 170-184, 1999.

VIANA, Maria Albertina N.. Eduardo Moreira, um construtor da diferença. 2 Vols. Dissertação de Mestrado, texto policopiado. Porto: Faculdade de Letras da Universidade do Porto, 1999.

VIDAL, Alexandra Silva. El archivo histórico de la iglesia lusitana (Comunión anglicana de Portugal): El reto de la organización, tratamiento y difusión de un archivo religioso en la web. In: ARIAS COELlO, Alicia \& García Sánchez, Diego (Coord.). Actas de las I Jornadas de Estudiantes de Ciencias de la Documentación "Compartiendo Conocimiento". Madrid: Universidad Complutense, [2017], p. 71-78.

VIDAL, Alexandra Silva; AFONSO, José António; SILVA, António Manuel S. P.. Contributo para o estudo da sociabilidade protestante no Portugal Contemporâneo: as Ligas de Esforço Cristão. In: Congresso Internacional SocyHume 2016 - Da sociabilidade ao património histórico e cultural. O Sul em perspectiva comparada, Séculos XVIII a XXI, Universidade de Évora, setembro de 2016. [No prelo].

Vila Nova de Gaia de há 100 anos. Colóquio comemorativo do centenário da igreja do Torne. Actas. V. N. Gaia: Junta Paroquial de São João Evangelista, 1995.

VOELTZEL, René. Éducation et Révélation. Introduction aux Problemes de la Pédagogie Chrétiene. Paris: PUF, 1960.

ZNANIECKI, Florian. Education for Democracy [c. 1940]. In: ZNANIECKI, Florian Education and Social Change. Ed. and int. by Elabieta Halas. Frankfurt and Main: Peter Lang, 1988, p. 41-121. 